Columbia Law School

Scholarship Archive

1981

\title{
A Structural Approach to Corporations: The Case Against Defensive Tactics in Tender Offers
}

Ronald J. Gilson

Columbia Law School, rgilson@law.columbia.edu

Follow this and additional works at: https://scholarship.law.columbia.edu/faculty_scholarship

Part of the Business Organizations Law Commons

\section{Recommended Citation}

Ronald J. Gilson, A Structural Approach to Corporations: The Case Against Defensive Tactics in Tender Offers, 33 StAN. L. REV. 819 (1981).

Available at: https://scholarship.law.columbia.edu/faculty_scholarship/983

This Article is brought to you for free and open access by the Faculty Publications at Scholarship Archive. It has been accepted for inclusion in Faculty Scholarship by an authorized administrator of Scholarship Archive. For more information, please contact scholarshiparchive@law.columbia.edu. 


\title{
A Structural Approach to Corporations: The Case Against Defensive Tactics in Tender Offers
}

\author{
Ronald J. Gilson*
}

Tender offers present an obvious and inherent conflict of interest between management and shareholders. On the one hand, an offer provides shareholders with the opportunity to sell their shares for a substantial premium over market price. On the other hand, the tender offer is the principal mechanism by which management can be forcibly unseated from control. ${ }^{1}$ It should thus come as no surprise that management often resists outsiders' efforts to direct tender offers at its shareholders. The form of that resistance, however, is somewhat surprising. Because the tender offer is the only form of corporate acquisition addressed directly to the target's shareholders, one might expect defensive tactics initiated by management to focus on persuading shareholders that the proffered transaction was not in their best interests. An offer would then fail because target shareholders found it unattractive. Reality, however, differs from expectation. Major forms of defensive tactics achieve success not because they convince target shareholders to retain their shares, but because they prevent the offer from being made, or if made, consummated, and thereby ensure that shareholders cannot make, from management's perspective, the "wrong" decision."

* A.B., Washington University, St. Louis; J.D., Yale University. Associate Professor of Law, Stanford University. The research for this article was supported by the Stanford Legal Research Fund, made possible by a bequest from the Estate of Ira S. Lillick, and by gifts from Roderick E. and Carla A. Hills and other friends of the Stanford Law School.

I am grateful to Lee Bollinger, Richard Buxbaum, Louis Cohen, Melvin Eisenberg, Bruce Gitelson, Thomas Jackson, Robert Mnookin, Mitchell Polinsky, Gerald Rosberg, and Kenneth Scott for their helpful comments on an earlier draft of this article. None, of course, bear any responsibility for the errors which doubtless remain except, perhaps, for Professors Bollinger and Rosberg, who do bear some burden for having gotten me into this line of work in the first place.

1. See text accompanying note 95 infra.

2. The literature cataloguing the array of defensive tactics which have been developed is vast. E.g. , E. Aranow, H. Einhorn \& G. Berlstein, Developments in Tender Offers 
Courts and regulatory authorities have long recognized this conflict between management's wish to retain control and the shareholders' wish to have access to the highest price for their stock. Responding to cases arising out of the first postwar acquisition wave, ${ }^{3}$ the Delaware Supreme Court first confronted the conflict more than 20 years ago, ${ }^{4}$ and the Securities Exchange Commission, in settings where a defensive tactic requires shareholder approval, has since 1969 required explicit disclosure of the potential foreclosure of shareholder access to desirable offers. ${ }^{5}$ But despite this long-standing recognition, state corporation law's resolution of the conflict continues to turn on management's motive in defeating the tender offer and thereby preventing a shift in control. In this article I will argue that emphasizing managerial motives cannot resolve the conflict and, indeed, does no more than offer a pretense for believing that the conflict does not exist.

The difficulty with the traditional approach, however, goes beyond the uncertainties of motivational analysis. It is not the reason for management's action which creates the conflict, but the fact that management acts at all. Resolving the conflict unavoidably requires delineating the appropriate roles of management and shareholders in control transactions. This effort, in turn, is possible only by expanding the sources which courts have traditionally considered relevant in developing corporation law. I will argue here that an appropriate allocation of authority between management and shareholders in the modern public corporation and, therefore, resolution of the conflict of interest inherent in the tender offer process, can be achieved only by carefully examining the entire structure of the modern corporation. And while the broad outline of this structure is sketched by the typical state enabling statute, its picture is completed

for Corporate Control (1977); P. Davey, Defenses against Unnegotiated Cash Tender Offers (1977); A. Fleischer, Tender Offers, Defenses, Responses, and Planning (1979); M. Lipton \& E. Steinberger, Takeovers \& Freeezeouts (1978); Hochman \& Folger, Defecting Takeovers: Charler and Bylaw Techniques, 34 Bus. LAw. 537 (1979); Reuben \& Elden, How to Be a Target Company, 23 N.Y.L.S. L. REv. 423 (1978); Wachtell, Special Tender Offer Litigation Tactics, 32 Bus. LAW. 1433 (1977).

3. G. Bentson, Conglomerate Mergers: Causes, Consequences, and RemeDIES 5-7 (1980) discusses the volume and timing of acquisitions since 1895.

4. Kors v. Carey, 39 Del. Ch. 47, 158 A.2d 136 (1960); see Cheff v. Mathes, 41 Del. Ch. 494, 199 A.2d 548 (1964); Bennett v. Propp, 41 Del. Ch. 14, 187 A.2d 405 (1962); Condec Corp. v. Lunkenheimer Co., 43 Del. Ch. 353, 230 A.2d 769 (1967).

5. Disclosure in Proxy and Information Statements; Anti-takeover or Similar Proposals, Securities Exchange Act Release No. 15,230, reprinted in [1978 Transfer Binder] FED. SEC. L. REP. (CCH) If 81,748, at 80,985 (Oct. 13, 1978). 
by nonlegal forces deriving from the markets in which the corporation and its participants function.

Part I of this article critically examines the traditional approach to regulating management efforts to prevent changes of control. Having argued that the traditional approach is incapable of resolving the conflict of interest presented by management defensive tactics, I will then offer in Part II what I term a "structural approach" to the problem. This approach exposes the invalidity of defensive tactics in tender offers and delineates a general principle governing management's appropriate role in the tender offer process. In Part III I address the various arguments used to justify management discretion to block a tender offer, and in Part IV describe the role which remains for management, a role substantially more limited than that management currently assigns to itself. Finally, in Part V I suggest a rule which implements the structural approach and then consider anticipated criticism of the rule.

\section{The Traditional Approach to Management's Role in TAKEOVERS: APPLYING THE FIDUCIARY PRINCIPLE IN Control SETTINGS}

In traditional terms, the question posed by management's implementing defensive tactics in response to a tender offer is whether management has acted in its own self-interest at the expense of the shareholders. Cast in doctrinal terms, the attack on such activities would be framed in terms of management's violating its fiduciary duty. Examining the development and content of traditional fiduciary analysis, however, demonstrates that it is incapable of resolving the problem posed by defensive tactics. Under prevailing legal standards, the common measure of fiduciary obligation is virtually without content where the conflict of interest triggering its application concerns maintaining control.

The scope of management's fiduciary responsibility and the measure of its discharge are traditionally described by the content of and interplay between two statements of obligation-the duty of care and the duty of loyalty-and the corresponding standards by which courts measure discharge of those obligations-the business judgment rule and the fairness test. The statements of obligation are in themselves unremarkable. The duty of care states that management owes the corporation reasonable diligence described by a traditional negligence formula: "A director shall perform his duties . . . with such care as an ordinarily prudent person in a like position would use 
under similar circumstances." 6 The duty of loyalty requires only that the director's dealings with the corporation be consistent with the "fiduciary" position held. " In both cases, the standards by which the discharge of these obligations is measured are of real significance.

\section{A. Duty of Care: The Business Judgment Rule}

The substance of the duty of care is contained in the measure of its discharge, the business judgment rule: "Absent bad faith or some other corrupt motive, directors are normally not liable to the corporation for mistakes of judgment, whether those mistakes are classified as mistakes of fact or mistakes of law." 8 In practice, however, the rule functions less as a standard of management conduct than as a statement of judicial restraint: "[T]he liability aspect of the rule may well have been incidental to its principal function. The rule is more likely to have survived because it functioned as a quasi-jurisdictional barrier to prevent courts . . . from exercising regulatory powers over the activities of corporate managers." Put this way, the business judgment rule does not express the measure by which a court determines whether management has discharged its duty of care; rather, its application reflects a conclusion that the management action in question will not be reviewed at all. ${ }^{10}$

6. ABA-ALI MODEL Bus. CORP. ACT ANN. 2D $\$ 35$ (Supp. 1977). The precise formulation differs from state to state. Compare CAL. CORP. CODE $\S 309$ (West 1977) with N.Y. Bus. CORP. LAW $\S 717$ (McKinney Supp. 1980-81). The statutes speak of a director's duty of care, but the duty extends to management as well. See, e.g., H. HENN, HANDBOOK OF THE LAW OF CORPORATIONS 453-57 (2d ed. 1970).

7. See, e.g., H. HENN, supra note 6 , at 457-59.

8. Cramer v. General Tel. \& Elec. Corp., 582 F.2d 259, 274 (3d Cir. 1978), cert. denied, 439 U.S. 1129 (1979). The recent popularity of the business judgment rule to justify the dismissal of shareholder derivative litigation has resulted in a flurry of judicial restatements of the principle, of which Cramer is one. See, e.g., Lewis v. Anderson, 615 F.2d 778 (9th Cir. 1979), cert. denied, 101 S. Ct. 206 (1980); Abbey v. Control Data Corp., 603 F.2d 724 (8th Cir. 1979), cert. denied, 444 U.S. 1017 (1980); Auerbach v. Bennett, 47 N.Y.2d 619, 393 N.E.2d 994, 419 N.Y.S.2d 920 (1979). But see Maldonado v. Flynn, 413 A.2d 1251 (Del. Ch. 1980) (dismissal not compelled by decision of independent directors not to sue). See generally Dent, The Power of Directors to Terminate Shareholder Litigation: The Death of the Derivative Suit?, 75 Nw. U. L. REv. 96 (1980).

9. Manne, Our Two Corporation Systems: Law and Economics, 53 VA. L. REv. 259, 271 (1967); see Note, The Continuing Viability of the Business Judgment Rule as a Guide for Judicial Restraint, 35 GEO. WASH. L. REv. 562, 564 (1967).

10. This view is consistent with Professor Bishop's oft-cited comment that "[ $t$ ]he search for cases in which directors of industrial corporations have been held liable in derivative suits for negligence uncomplicated by self-dealing is a search for a very small number of needles in a very large haystack." Bishop, Sitting Ducks and Decoy Ducks: New Trends in the Indemnification of Corporate Directors and Officers, 77 YALE L.J. 1078, 1099 (1968). It has been recently argued that even those cases, such as Litwin v. Allen, 25 N.Y.S.2d 667 (1940), commonly cited as the 
The courts' abdication of regulatory authority through the business judgment rule may well be the most significant common law contribution to corporate governance. Although critics have complained that the "[d]irectors' duty of due care has almost been interpreted out of existence," "11 a broader judicial role is difficult to justify. First, courts are ill-suited to review the wisdom of complex business judgments; ${ }^{12}$ it is, for example, almost impossible to distinguish between acts of corporate social responsibility and acts of long-term profit maximization. ${ }^{13}$ Second, even if such a review were possible, it seems virtually certain that the game would not be worth playing.

By definition, the issue of managerial performance arises only after a decision has turned out badly, and a court could accomplish little at this stage. The impact of the court's decision on future management does not justify judicial review. A general directive to be wise rather than foolish is of little help. More specific remarks concerning the wisdom of the competing alternatives and the manner in which they might better have been evaluated, even if correct, are unlikely to prove a source of guidance for future managers. And, in any event, litigation is an unjustifiably expensive way to develop a case study to aid in future business decisions.

Nor can more rigorous judicial review of managements' business decisions be justified as a mechanism of shareholder protection. The risk that the corporation will not succeed in the marketplace due to poor managerial judgment relative to the competition is reflected in the price paid for the stock. Little controversy remains concerning the proposition that the market for most publicly traded securities is efficient in the semistrong form; that is, that the price of the security at any time reflects all public information about a company, including knowledge about management's abilities and its attitude toward

rare examples of violations of the duty of care, are explainable only on the basis of other concerns. Phillips, Managerial Misuse of Property: The Synthesizing Thread in Corporate Doctrine, 32 RUTGERS L. REV. 184, 203-09 (1979).

11. Weiss, Disclosure and Corporale Accounlability, 34 Bus. LAw. 575, 587 (1979); see Cary, Federalism and Corporate Law: Reflections Upon Delaware, 83 YALE L.J. 663 (1974).

12. On occasion this point is acknowledged by a court asked to consider applying the business judgment rule. E.g., Auerbach v. Bennett, 47 N.Y.2d 619, 630, 393 N.E.2d 994, 1000,419 N.Y.S.2d 920, 926 (1979) ("It appears to us that the business judgment doctrine, at least in part, is grounded in the prudent recognition that courts are ill equipped and infrequently called on to evaluate what are and must be essentially business judgments."); see Manne, The "Higher Criticism" of the Modern Corporation, 62 ColuM. L. REv. 399, 421-22 (1962).

13. Engel, An Approach to Corporate Social Responsibility, 32 StaN. L. REv. 1, 15-16 (1979). 
risky ventures. ${ }^{14}$ Shareholders can cheaply insure against the various risks of business failure by investing in a diversified portfolio. ${ }^{15}$ There is no reason for management to insure separately against only one of the causes-poor business judgment.

Finally, judicial review, and the resulting potential for personal liability, cannot be justified as a necessary incentive for managers to behave responsibly. It is now widely recognized that a variety of markets-product, employment, capital, and corporate controlconstrain inefficient management performance without the enormous transaction costs associated with litigation. ${ }^{16}$ In short, the business judgment rule's wisdom-its declination to provide judicial regulation when other forces more cheaply accomplish the same end-is precisely what generates its most persistent criticism. It also, however, identifies the limits of its application.

\section{B. Duty of Loyalty: The Policy Confict/Primary Purpose Test}

While the business judgment rule acts as a jurisdictional barrier to review of most managerial decisions, the common law also recognizes that regulation of management conduct is appropriate where management has a conflict of interest. Drawing on trust law doctrine by analogy, the duty of loyalty originally prohibited transactions between a corporation and its management. ${ }^{17}$ This restriction, however, was bent over time to reflect commercial necessity. Prohibition gave way to an overriding emphasis on the substantive fairness of the transaction. ${ }^{18}$ In contrast to judicial restraint under the business judgment rule, courts adopted an active regulatory posture with respect to transactions posing conflicts of interest: A court would "review such a contract and subject it to rigid and careful scrutiny, and would invalidate the contract if it was found to be unfair to the cor-

14. See Jensen, Some Anomalous Evidence Regarding Market Efficiency, 6 J. FIN. ECON. 95, 96 (1978) ("TT]here is no other proposition in economics which has more solid empirical evidence supporting it than the efficient market hypothesis."). For discussion of the empirical evidence, see G. Foster, Financial Statement ANalysis (1978) (describing post-1973 studies); J. LORIE \& M. HAMILTON, The STOCK MARKET: TheORIES AND Evidence 70-97 (1973).

15. See note 121 infra and accompanying text.

16. Among recent works by lawyers, see, e.g. , R. POSNER, ECONOMic ANALYSIS OF LAw 300-13 (2d ed. 1977); R. WINTER, GOVERNMENT AND THE CORPORATION 5-46 (1978); Anderson, Conficts of Interest: Efficiency, Faimess and Corporate Sinucture, 25 U.C.L.A. L. REv. 738, 784-87 (1978); Werner, Management, Stock Market and Corporate Reform: Berle and Means Reconsidered, 77 CoLUM. L. REV. 388, 389 (1977).

17. See generally Marsh, Are Directors Trustees?, 22 Bus. LAw. 35 (1966); Phillips, supra note 10 .

18. The classic formulation of this development is that of Harold Marsh, supra note 17. 
poration." 19 To be sure, fairness did not offer talismanic precision. A "fair" price is no more than one set somewhere between the lowest price a seller will accept and the highest price a buyer will pay. But the concept does offer an objective measure; recourse to comparable market transactions is possible and appraisals, although inexact, are available. This allows the structuring of beneficial transactions with some certainty of their consequences and without enormous regulatory costs. ${ }^{20}$ In short, the fairness standard is a thoroughly respectable rule of law as applied to the area of its original application.

The fairness standard, however, has been an inadequate measure of management's discharge of its duty of loyalty in the area of particular concern here-its application in the context of change of control. Indeed, it was never tried. There is little question that management is subject to a conflict of interest when confronted with a proposal for the corporation's acquisition. As Harold Marsh has commented, "It is impossible to command the directors in this situation to avoid any conflict of interest, since it has been unavoidably thrust upon them." 21 Because corporate statutes commonly require the approval of the target's board of directors before a proposed merger or sale of assets can even be put to the shareholders, most acquisitions cannot be undertaken without management consent. ${ }^{22}$ As a result, management can reject offers beneficial to shareholders to retain the emoluments, both pecuniary and nonpecuniary, that flow from a position of high authority in a public corporation. Alternatively, control over access to shareholders gives management the

19. Marsh, supra note 17 , at 43 .

20. Professor Phillips has recently argued that the evolution of the fairness standard represents yet another instance of the economic efficiency of the common law. Phillips, supra note 10. One cost of contracting is the production of information about the other partyintegrity, truthfulness, credit, etc.-necessary to successful negotiations. Where the parties have a preexisting relationship, as that between a director and the corporation, costs are lower because the parties already have the benefit of the information concerning each other resulting from the preexisting relationship. The problem of conflict of interest can then be characterized as one of allocating the savings resulting from reduced transaction costs, and the allocation principle can be characterized as fairness. Id. at 191-92. A similar point is made in R. WINTER, supra note 16, at 34-35. For a comparable argument in a related context, see Brudney \& Chirelstein, Fair Shares in Corporate Mergers and Takeovers, 88 HARv. L. REV. 297 (1974).

21. Marsh, supra note 17, at 60; see Herzel, Schmidt \& Davis, Why Corporale Directors Have a Right to Resist Tender Offers, 61 CHI. B. REC. 152, 158 (1979). The inevitability of the conflict has also been recognized judicially: "[W] henever a tender offer is extended and the management of the threatened company resists, the officers and directors may be accused of trying to preserve their jobs at the expense of the corporation." Northwest Indus., Inc. v. B.F. Goodrich Co., 301 F. Supp. 706, 712 (N.D. Ill. 1969).

22. See notes 89-91 infra and accompanying text. 
power to "sell" that access to an offeror for such things as favorable employment contracts and attractive treatment of existing fringe benefits like stock options. ${ }^{23}$ Thus, it is impossible to identify at the outset any path management might take which would eliminate the inherent conflict of interest; any action, whether rejection or approval, reflects the potential for diversion of benefit to management and away from shareholders. ${ }^{24}$

A potential acquisition thus seems the paradigmatic setting for judicial regulation of management conduct. While the absence of judicial review was sensible in nonconflict settings because other constraints protected shareholders, the conflict of interest inherent in a potential change in control called for "rigid and careful scrutiny" of the fairness of management conduct. But while doctrinal logic demanded such a review, it did not occur. Faced with the problem of attempting to police management behavior in this setting, the courts abdicated, albeit, I will suggest, in an inventive manner.

The difficulty in policing management conduct in connection with changes of control, and the devices by which the courts chose to avoid the task, can best be seen by considering two common defensive tactics. In the first, a third party acquires a significant minority of shares ${ }^{25}$ and seeks either to acquire the remainder of the target's shares or to make substantial changes in the target's operations. Target management opposes either course and, after more or less conflict, the target corporation resolves the issue by repurchasing the dissident's shares at a price higher than market. ${ }^{26}$ In the second, an offeror announces its intent to tender for control and target management takes action-like placing a significant amount of the target's common stock in hands sympathetic to management's desire to re-

23. See, e.g., Manne, Mergers and the Market for Corporate Control, 73 J. PoL. Econ. 110, 117-18 (1965) [hereinafter cited as Market for Corporate Control]; Manne, Some Theoretical Aspects of Share Voting, 64 Colum. L. REv. 1427, 1437-38 (1964) [hereinafter cited as Share Voting].

24. The third possibility, neutrality, is not possible for a merger or sale of assets, which require director approval. See note 90 infra. For a tender offer, it has much the effect of approval and is subject to similar problems.

25. A pre-offer accumulation of a significant position in the target's stock, now commonly referred to as making a "block purchase," is intended both to exert leverage over the target and to prevent others from joining the bidding for the target. $1 \mathrm{M}$. LIPTON \& $\mathrm{E}$. STEINBERger, supra note 2, at 57; Freund \& Easton, The Three-Piece Suitor: An Allemative Approach to Negotialed Corporate Acquisitions, 34 Bus. LAw. 1679 (1979). A block purchase also acts as insurance against loss if a competing offeror is ultimately successful. See notes 184-87 infra and accompanying text.

26. The financial characteristics of some recent transactions of this type are described in More Firms Paying Premium Prices to Wrest Shares from Antagonists, Wall St. J., Jan. 8, 1981, at 21, col. 4. 
main independent-which prevents the change in control from occurring.

In the first setting, where the management action taken-repurchase of the outsider's stock-has as its announced purpose preventing a shift in control of the corporation, the conflict of interest is apparent. Reviewing management's action under the fairness standard, however, presents substantial difficulties. Inquiry could be made concerning whether the price paid by the company was fair, but in that sense, the transaction was arm's length; management had no interest in paying more for the shares than was necessary to convince the holder to sell. ${ }^{27}$ Moreover, that the price was "fair" only demonstrates the irrelevancy of the inquiry. Management's conflict of interest was not in the price paid, but in the decision to acquire the shares at all. Applying a fairness standard to this decision, however, requires a court to determine whether it was "fair" for control to remain with management rather than shift to the offeror. And this inquiry must necessarily focus on whether the shareholders would be better off with existing management or by selling their shares. But this is an investment decision, made continually by shareholders in deciding whether to sell their shares, and raises the same issue of judicial competence which justifies a restrictive judicial role with respect to the duty of care. ${ }^{28}$

In the second setting, where the management action taken-a sale of target shares to a friendly party-has the effect of blocking a potential change in control, a court could also evaluate whether the price received for the shares was fair. As in the first setting, however, inquiry into the fairness of the price is beside the point; management's conflict of interest goes not to the commercial reasonableness of the defensive action's terms, but to the decision to block a change in control. As in the first setting, a fairness review of the relevant conflict forces the court to consider precisely the factors which the business judgment rule excludes from consideration.

The manner in which the courts sidestepped this dilemma is a marvel of doctrinal development. The first setting is recognizable as Cheff v. Mathes, ${ }^{29}$ where the Delaware Supreme Court avoided the

27. It is true, however, that management's conflict of interest impacts management's ability to bargain strategically. Thus, management may be less inclined to engage in hard bargaining than might the shareholders.

28. See notes 12-16 supra and accompanying text; M. EISENBERG, The STRUCTURE OF THE CORPORATION 34 (1976) (noting difficulty of applying "usual conflict of interest rules" where there is "no market against which the transaction can be measured").

29. 41 Del. Ch. 494, 199 A.2d 548 (1964). For similar situations, see, e.g., Heine v. 
problem by shifting the focus of the inquiry. If the court was illequipped to review the fairness of management's belief that it was the better repository for future control of the corporation, it was at least competent to engage in an inquiry with which it was familiar, a review of motive:

[T] he allegation is that the true motives behind such purchases were improperly centered upon perpetuation of control. . . . [I]f the actions of the board were motivated by a sincere belief that the buying out of the dissident stockholder was necessary to maintain what the board believed to be proper business practices, the board will not be held liable for such decision . . . . On the other hand, if the board has acted solely or primarily because of the desire to perpetuate themselves in office, the use of corporate funds for such purposes is improper. ${ }^{30}$

Recognizing that inventive counsel could always discover a conflict over policy between management and an insurgent, the court required an additional showing: that the board's determination that a policy conflict existed was based on "reasonable investigation."31

While the Cheff decision has been extensively criticized, ${ }^{32}$ note how neatly the court avoided the fairness dilemma. A conflict of interest existed which, in the court's view and, I think, in fact, was not subject to a traditional fairness review. An analysis of management's motives then served as a surrogate for a fairness review to validate the transaction: Where management's investigation demonstrates that a policy difference was the motivation for the transaction, then the conflict of interest has been exorcised. Absent a conflict of inter-

Signal Cos. [1976-1977 Transfer Binder] FED. SEC. L. REP. (CCH) ๆ 95,898 (S.D.N.Y. 1977); Kaplan v. Goldsamt, 380 A.2d 556 (Del. Ch. 1977). See generally Nathan \& Sobel, Corporate Slock Repurchases in the Context of Unsolicited Takeover Bids, 35 Bus. LAw. 1545 (1980).

30. 41 Del. Ch. at 504, 199 A.2d at 554.

31. Id. at 506, 199 A.2d at 555. But management can easily overcome this hurdle by developing appropriate documents. See Israels, Corporale Purchase of Its Own Shares-Are There New Overtones?, 50 CORNELl L.Q. 620, 624 (1965). For proxy fights, the policy conflict requirement is, similarly, almost without content. See note 92 infra and accompanying text.

32. See, e.g. , Brudney, Fiduciary Ideology in Transactions Affecting Corporale Control, $65 \mathrm{MiCH}$. L. REV. 259, 270 (1966); Israels, supra note 31, at 624. The distinction between self-perpetuation and conflict over policy originally surfaced as the standard which determined whether incumbent management could use corporate funds in a proxy contest. See Campbell v. Loew's Inc., 36 Del. Ch. 563, 134 A.2d 852 (1957); Rosenfeld v. Fairchild Engine \& Airplane Corp., 309 N.Y. 168, 173, 128 N.E.2d 291, 293 (1955). One might justify expenditure of corporate funds in a proxy contest because the funds are used to provide shareholders with information that will help them decide how to vote. But expenditure of funds to repurchase a potential tender offeror's shares serves not to aid the shareholder's decision between competing contestants for control, but to foreclose that decision entirely. See M. EisenberG, supra note 28 , at 105 n.31. 
est, the business judgment rule is the appropriate standard of review, precisely the standard applied by the court in Cheff:

[T] he directors satisfy their burden by showing good faith and reasonable investigation; the directors will not be penalized for an honest mistake of judgment, if the judgment appeared reasonable at the time the decision was made. ${ }^{33}$

Since management can almost always find a conflict over policy between itself and an insurgent, ${ }^{34}$ the motive analysis collapses into the business judgment standard. And while this approach neither solved nor addressed management's conflict of interest, it did eliminate substantive review of questions which the court was institutionally incompetent to resolve.

The second setting arose in Northwest Industries, Inc. v. B.F. Goodrich Co. ${ }^{35}$ Goodrich was a participant with Gulf Oil in a joint venture which both had concluded would be more valuable if owned by either entirely. Despite extensive negotiations, the parties could not agree upon a price at which Goodrich would acquire Gulf's interest, and so the matter stood for some four years. Then, ten days after the announcement of a tender offer for Goodrich by Northwest, negotiations reopened and, in a single day, without further study, Goodrich management agreed to acquire Gulf's interest in exchange for 700,000 shares of authorized but unissued Goodrich common stock. ${ }^{36}$ The Goodrich board approved the transaction the following day on the basis of "a hastily prepared two page memorandum and a one page statistical analysis of the transaction."37 Northwest sued to block the transaction, claiming that the stock issuance was a mechanism to defeat the Northwest tender. ${ }^{38}$

33. 41 Del. Ch. at 506, 199 A.2d at 555 .

34. See, e.g. , Braude v. Havenner, 38 Cal. App. 3d 526, 532, 113 Cal. Rptr. 386, 389 (1st Dist. 1974) ("[E]very contest involves or can be made to involve issues of policy.").

35. 301 F. Supp. 706 (N.D. Ill. 1969).

36. The court noted that "[w]hile Gulfs officers had updated their 1965 studies of Chemicals [the joint venture], the only Goodrich documents were a brief, handwritten memorandum of possible valuations of Gulf's one-half interest and a sheet of paper containing longhand calculations." Id. at 709 n.3.

37. Id. at 709.

38. Although the court's opinion considers only the Gulf transaction, it was not the only defensive tactic undertaken by Goodrich. The Goodrich defense included litigation claiming violation by Northwest of the federal securities laws, political pressure, an additional defensive acquisition designed to create an antitrust barrier, and the proposal of shark repellent amendments. See O. Williamson, Corporate CONTROL AND Business BehavioR 100-02 (1970). 
While the price paid for the joint venture could be reviewed in traditional fairness terms, ${ }^{39}$ the court also had to deal with the claim that the transaction should not have taken place at any price. And this inquiry was particularly difficult because the court had to acknowledge that it was the Northwest tender offer which triggered the transaction. ${ }^{40}$ Nonetheless, the court avoided reviewing the "fairness" of Goodrich's resistance by analyzing motive instead. While acknowledging that one of Goodrich's motives was to defeat the offer, the court expressly rejected the contention that " where a board of directors has as one of its motives manipulation for control the transaction is invalid, regardless of fairness, and regardless of whether a legitimate corporate purpose is also being served." "41 Only if "Goodrich officials' desire to remain in office was the sole or the primary motive for their decisions" 42 would resistance breach the duty of loyalty. Where dual motives are present-maintaining control and furthering a legitimate corporate interest-the conflict of interest is eliminated and the appropriate standard, as in Cheff, is the business judgment rule: "Goodrich's officers and directors appear to have been exercising their honest business judgment, so that their decision is conclusive." 43

Despite the doctrinal ingenuity by which the policy conflict/primary purpose test avoids the impossible task of substantive judicial review of the merits of conflicting claimants for corporate control, the central problem still remains: Blocking a change in control may reflect management's self-interest regardless of policy differences with a rival for control, and regardless of whether the defensive tactic chosen also serves an unrelated corporate purpose. This approach converts the issue from one of duty of loyalty to one of duty of care, with the consequent "incongruity of applying a standard designed to vindicate the exercise of business judgment in non-conflict-of-interest situations as a measure of compliance with the duty of

39. $301 \mathrm{~F}$. Supp. at 710. Among Northwest's claims was an assertion that the price paid by Goodrich for the Gulf joint venture interest was too high.

40. Id. at 712 ("Northwest's tender offer announcement galvanized Goodrich and Gulf to complete the purchase at this time.").

41. Id. (quoting Cummings v. United Artists Theatre Circuit, Inc., 237 Md. 1, 21, 204 A.2d 795, 805 (1964)).

42. Id.

43. Id. Recent cases have consistently followed this standard. See, e.g., Treadway Cos. Inc. v. Care Corp., [1980 Transfer Binder] FED. SEc. L. REP. (CCH) I] 97,603, 98,210-11 (2d Cir. 1980); Heit v. Baird, 567 F.2d 1157, 1161 (1st Gir. 1977); Panter v. Marshall Field \& Co., 486 F. Supp. 1168, 1186 (N.D. Ill. 1980), affd, Nos. 80-1375, 80-1389 (7th Cir. April 2, 1981); Berman v. Gerber Prods. Co., 454 F. Supp. 1310, 1319 (W.D. Mich. 1978). 
loyalty, which arises only in conflict-of-interest situations." 44 So long as the policy conflict/primary purpose test is applied, management's conflict of interest cannot be and, I have argued, was not intended to be, confronted.

The courts were led to this impasse because they concentrated narrowly on the appropriateness of management conduct in the case at hand, an inquiry which, unless limited, would necessarily involve the court in an exercise resembling fundamental security analysis, rather than approaching the problem through a broader examination of the appropriate allocation of responsibility between management and shareholders with respect to change in control. This approach requires an understanding of the structure of the modern, publicly held corporation, including particularly the role of nonstatutory elements like economic markets. The next part develops this structure and, from it, a general principle governing the role of management in opposing a change in corporate control.

\section{A Structural Approach to Tender Offer Defenses}

Whatever the attraction of reasoning based on extrastatutory relationships and interactions in other areas of the law, it might have been expected to dominate in corporation law, whose doctrinal core can be explained only on a structural rather than a textual basis. This point, and what I mean by a structural approach, can be clarified by considering how that doctrinal core developed.

"American corporate statutes . . . are in no sense a code of company law . . . ." "45 Typical statutes provide only a skeletal arrangement of the various parts of the corporate entity. As a result, extrastatutory principles early developed which fleshed out the skeleton by defining the function of, and relationship among, the statutory elements. Perhaps the best example of the addition of extrastatutory flesh to statutory bone is the fiduciary duty doctrine itself. Although the typical corporation statute vests management with the power to direct the corporation's business, ${ }^{46}$ management's

44. Brudney, supra note 32, at 274. In Johnson v. Trueblood, 629 F.2d 287, 292 (3d Cir. 1980), Chief Judge Seitz recognized this incongruity but asserted, without citation of authority, that the result was intentional: "The business judgment rule seeks to alleviate this problem [unavoidable conflict of interests] by validating certain situations that otherwise would involve a conflict of interest for the ordinary fiduciary." Embracing the effect of the subterfuge as intended, however, is only another, less inventive, means of avoidance.

45. M. EISENBERG, supra note 28 , at 86 (quoting, in part, L. Gower, The Principles OF MODERN COMPaNy LAW 8 (2d ed. 1957)).

46. E.g. , Cal. Corp. Code $\S 300$ (West 1977); Del. Code ANn. tit. 8, § 141 (1975 \& 
obligations to the corporation and shareholders were not historically the subject of statutory explication. While specific duties and liabilities were outlined with respect to particular obligations like dividend payments, ${ }^{47}$ there was typically no mention of a more general duty of care or loyalty. Nor is legislative silence solely an historical phenomenon. The corporation laws of some 30 states, including Delaware, still do not contain a standard of director conduct, and of those which now do contain such a standard, many were enacted only following the addition of section 35-a statutory specification of director obligation-to the Model Business Corporation Act in 1975. ${ }^{48}$

But legislative silence did not prevent standards from developing; it was merely left to the courts to develop the concepts of fidelity and care which have defined the obligations of corporate management. ${ }^{49}$ And the sources to which the courts turned implicitly acknowledged the centrality of issues of structure and relationship. Recognizing that corporate statutes created an entity in which management of individuals' property was placed in the hands of representatives, the courts established the character of management responsibility by referring to that relationship. Since the relationship was representative, the courts took from trust and agency law the concept of fiduciary duty. ${ }^{50}$

Moreover, the steady divergence of corporate "fiduciary" law from its trust law ancestor reflected changes not in the corporate statute, but in the character of the parties to the relationship and in the economic environment in which the corporation functioned. ${ }^{51}$ Indeed, the fiduciary obligation evolved despite the statute. It is now

Supp. 1980); N.Y. Bus. CoRP. LAW $§ 701$ (McKinney 1963 \& Supp. 1980-81); ABA-ALI MODEl Bus. CoRp. ACT ANN. 2d $\S 35$, at 253 (Supp. 1977) (as revised in 1974).

47. E.g. , CAL. CORP. CODE $\$ 316$ (West Supp. 1980) (directors' liability for distributions, loans, and guarantees); DEL. CODE ANN. tit. 8, § 174 (1975) (liability of directors for unlawful payment of dividend or unlawful stock purchase or redemption); ABA-ALI MODEL Bus. CORP. ACT ANN. 2d $\S 48$ (Supp. 1977) (liability of directors in certain cases).

48. ABA-ALI MOdel Bus. CoRP. ACT ANN. 2d § 35, at 270 (Supp. 1977); see Report of the Committee on Corporate Laws: Changes in the Model Business Corporation Act, 30 Bus. LAw. 501 (1975). The controversy over codification of the standard of director obligation continues. Compare Veasey \& Manning, Codified Standard -Safe Harbor or Uncharted Reef? An Analysis of the Model Act Standard of Care Compared with Delaware Law, 35 Bus. LAw. 919, 921 (1980), with Arsht \& Hinsey, Codified Standard-Same Harbor but Charted Channel: A Response, 35 Bus. LAw. 947 (1980).

49. A. Conard, Corporations in Perspective 34-35 (1976); J. Hurst, The LegitIMACY OF THE BUSINESS CORPORATION IN THE LAW OF THE UNITED STATES 1780-1970, at 98 (1970); Latty, Why Are Business Corporation Lawes Largely "Enabling"?, 50 CORNELl L.Q. 599, 606 (1965).

50. See note 17 supra.

51. See note 18 supra and accompanying text. 
commonplace that corporate actions which satisfy the terms of the statute in all respects may be set aside if they conflict with a nonstatutory obligation derived from the structure of the statute. Singer $v$. Magnavox $\mathrm{Co}_{0}{ }^{52}$ and its progeny, ${ }^{53}$ in which the fiduciary obligation was held to override strict compliance with the statutory requirements for mergers, are only the most recent examples. ${ }^{54}$

The skeleton of the corporation is created by statute, but the functioning of the complete entity is not statutorily defined. Guidance comes from the structure itself, from the relationships and interactions-some statutory, others not-which determine corporate behavior. This Part describes the broader structure of the corporation and, on that basis, demonstrates that management's power to oppose tender offers should be severely limited.

\section{A. The Structure of the Corporation and the Theory of the Firm}

All corporate statutes define the corporate skeleton in essentially identical terms. Owners of freely transferable voting securities elect a board of directors which, in turn, selects executive officers who, with the help of lesser employees, manage the business of the corporation. ${ }^{55}$ The remainder of the corporate structure and the behavioral characteristics exhibited by the various participants depend heavily on matters not the subject of statutory concern. For the publicly held corporation, the markets in which the corporation participates-product, managerial, and capital-are the central determinants of that structure and behavior. To understand the role these markets play in the structure of public corporations, we must begin at what was the beginning of modern corporate analysis- the separation of ownership and management.

52. 380 A.2d 969 (Del. 1977).

53. E.g., Roland Int'l Corp. v. Najjar, 407 A.2d 1032 (Del. 1979); Tanzer v. International Gen. Indus., Inc., 379 A.2d 1121 (Del. 1977) (although reported in an earlier volume of the Allantic Reporter, Tanzer was decided after Singer); of. Schnell v. Chris-Craft Indus., 285 A.2d 437 (Del. 1971) (fiduciary duty prevents advancing date of annual meeting despite compliance with relevant statutory requirements). See generally Brudney \& Chirelstein, A Restatement of Corporate Freezeouts, 87 YALE L.J. 1345 (1978); Greene, Corporate Freeze-out Mergers: $A$ Proposed Analysis, 28 STAN. L. REv. 487 (1976).

54. See A. ConARD, supra note 49, at 33-34; M. EISENBERG, supra note 28 , at $86-94$.

55. The text, while accurately describing the central role of executive officers with respect to actual management of the corporation, is an inaccurate description of the process by which directors and executive officers are selected. In most publicly traded corporations, the board of directors is selected by senior management rather than, as the statute contemplates, selection of senior management by the board. This phenomenon, and the literature dealing with it, are thoroughly reviewed in M. EISENBERG, supra note 28 , at 139-70. 
That the identity of the nominal owners of a public corporation-the shareholders-and those managing it diverged resulted inevitably from industry's capital needs in an expanding economy. The founder of a business, lacking the personal resources to exploit available opportunities, turned to outside sources of capital to finance expansion. As capital flowed into the corporation from nonmanagement sources, so did overall ownership of the corporation flow to the providers of capital. As Berle and Means stressed in their classic work, "[i]t is precisely this separation of control from ownership which makes possible tremendous aggregations of property."56

As the number of shareholders increased, separating the management function from the function of providing capital also became affirmatively desirable. Active managerial participation by shareholders faces enormous barriers. First, acquiring the information necessary to participate in corporate management is costly. Even if the corporation, as the least costly producer, distributed such information, the shareholder time necessary to understand and evaluate the information is still significant. Second, the cost of coordinating shareholder participation-of creating mechanisms to determine what decision the shareholder owners had made-is also great. ${ }^{57} \mathrm{Fi}$ nally, successful management of a large corporation requires specialized skills which individual shareholders are unlikely to possess. It is therefore beneficial for those having capital but lacking managerial expertise to hire those with expertise at managing capital but lacking the capital to manage. ${ }^{58}$ As Professor Clark has recently commented, "the assertion of any individual shareholder that he knows better than the managers how to run the company borders on hubris."

The advantages of centralized, specialized management, however, are not without cost. Management monitors the performance

56. A. Berle \& G. Means, The Modern Corporation and Private Property 5 (1932); see Manne, supra note 9, at 261. My description of shareholders as the "owners" of the corporation does not suggest that the role described for them in the following pages flows, normatively, from their "ownership." It derives, rather, from the need for those holding the residual interest in corporate profits to have the means to displace management which performs poorly. As will be apparent, this position is based on matters other than a preconception of the rights associated with "ownership"; indeed, if the statute did not provide for shareholders we would have to invent them.

57. See, e.g., J. Buchanan \& G. Tullock, The Galculus of Consent (1962); R. POSNER, supra note 16, at 303; Anderson, supra note 16, at 778-79; Clark, Vole Buying and Corporale Law, 29 CASE W. RES. L. REv. 776, 788 (1979); Heymann, The Problem of Coordination: Bargaining and Rules, 86 HARV. L. REV. 797, 831-33 (1973).

58. See, e.g., Anderson, supra note 16, at 775-76.

59. Clark, supra note 57 , at 788-89. 
of components of the enterprise in order to achieve efficient production. ${ }^{60}$ But a mechanism is necessary to ensure that management carries out its monitoring function efficiently; the performance of management must also be monitored, and hiring yet another team of monitors merely recreates the problem one level removed. ${ }^{61}$ What succeeds in short-circuiting the process is a reward system that allows the monitor to retain the benefits of the successful discharge of its function; self-interest is substituted for supervision to encourage efficient monitoring. ${ }^{62}$ This describes, of course, the close corporation, where the owners-the residual claimants who benefit from the increased profits resulting from efficient production-are also the management. In the public corporation, however, ownership and management are separated, and "the cost of . . . production is increased because the residual claim is not held entirely by the central monitor." 63

60. Alchian \& Demsetz, Production, Information Costs and Economic Organization, 62 AM. ECON. REv. 777, 782 (1972).

61. Alchian and Demsetz ask: "But who will monitor the monitor?" Id. at 782. The best description of the problem I have discovered is that in T. GeISSEL (DR. SEuSs), Did I Ever Tell You How Lucky You ARE? 26-29 (1973) (emphasis in the original):

"Oh, the jobs people work at!

Out west, near Hawtch-Hawtch,

there's a Hawtch-Hawtcher Bee-Watcher.

His job is to watch...

is to keep both his eyes on the lazy town bee.

A bee that is watched will work harder, you see.

Well ... he watched and he watched.

But, in spite of his watch, that bee didn't work any harder. Not mawtch.

So then somebody said,

"Our old bee-watching man

just isn't bee-watching as hard as he can.

He ought to be watched by another Hawtch-Hawtcher.

The thing that we need

is a Bee-Watcher-Watcher."

WELL . . .

The Bee-Watcher-Watcher watched the Bee-Watcher.

He didn't watch well. So another Hawtch-Hawtcher

had to come in as a Watch-Watcher-Watcher.

And today all the Hawtchers who live in Hawtch-Hawtch

are watching on Watch-Watcher-Watchering-Watch,

Watch-Watching the Watcher who's watching that bee.

You're not a Hawtch-Hawtcher. You're lucky, you see."

I am grateful to Catherine Hillary Gilson and Rebecca Ann Gilson for calling this source to my attention. To be fair, Dr. Seuss does ignore the likelihood that some monitoring will be at least partially effective. See note 72 infra.

62. Alchian \& Demsetz, supra note 60 , at 783.

63. Id. at 786 . 
The costs resulting from delegating the monitoring responsibility to professional management have been more precisely developed by Jensen and Meckling. ${ }^{64}$ Management acts as agents of the shareholders. They can be expected, if otherwise unconstrained, to maximize their own welfare rather than the shareholders'. As a result, it is in the owners' interests to incur "monitoring" costs: expenditures like third-party audits, designed to make it more difficult for management to prefer itself at the expense of the shareholders. But even third-party monitoring cannot be fully effective, ${ }^{65}$ and it will also be in the owners' interests to provide profit-sharing incentives designed to reduce the divergence of interests between management and shareholders. ${ }^{66}$

The sum of these costs-of efforts to prevent management from favoring itself and to positively motivate management to operate in the shareholders' interests-- together with the loss in potential value of the enterprise resulting from the inability to entirely prevent divergence of management and shareholder interest, "are the costs of 'separation of ownership and control" " in the public corporation. ${ }^{67}$

\section{B. Constraints on Management Discretion}

Understanding the roles of management and shareholders in the structure of the modern public corporation thus requires considering when and how that structure dissuades management from acting other than in the shareholders' best interest. For my purpose, the opportunities for management to favor itself at the expense of share-

64. Jensen \& Meckling, Theory of the Firm: Managerial Behavior, Agency Costs and Oumership Structure, 3 J. Fin. ECON. 305 (1976).

65. The more specialized the management function becomes, the more difficult the problem becomes. "The more complicated the service or the product, the more difficult and costly it is to detect cheating, and the more likely it is that cheating will occur." Anderson, supra note 16 , at 740 . Moreover, securing the benefits of specialization requires that the provider of the service be given the discretion to use its expertise. Since the effect of monitoring is to reduce the discretion accorded the specialist, it also reduces the amount of benefits arising from the specialist's services. Id. at 744 .

66. Incentive plans are also never fully effective. It is difficult to design a plan which measures only the performance of a single manager undiluted by the efforts of others. Moreover, once the performance measures are specified, strategic behavior is possible which manipulates the system in a fashion which favors participants without achieving the productivity gains intended. See, e.g., Rappaport, Executive Incentives vs. Corporate Growth, HaRv. Bus. REv., July-Aug. 1978, at 81; Some Middle Managers Cut Comers to Achieve High Corporate Goals, Wall St. J., Nov. 8, 1979, at 1, col. 6. These problems are attracting increasing popular attention. See Meadows, New Targeting for Executive Pay, ForTune, May 4, 1981, at 176.

67. Jensen \& Meckling, supra note 64, at 327; see Fama, Agency Problems and the Theory of the Firm, 88 J. POL. ECON. 288, 296 (1980). 
holders fall into two broad categories. First, management may be inefficient-if the managers worked harder, or were more careful, or were smarter, the shareholders' return might increase. This inefficiency affects shareholders by reducing production and therefore the amount of the corporation's income. Second, management may appropriate part of the corporation's income stream. For example, management may engage in transactions with the corporation which are unfair to the corporation, may provide itself luxurious office facilities or other perquisites, or in some other fashion may retain for itself more than a competitive return for managerial services. ${ }^{68}$ These two forms of managerial discretion are limited by several mechanisms, important aspects of which are market rather than legal.

Management's self-interest should constrain significant deviation from efficient operation. ${ }^{69}$ The viability of the corporation, critical to both the shareholders' investment and management's continued employment, depends on the corporation's success in the market for the good or service it provides. Competition in the product market will penalize a company with inefficient management. ${ }^{70}$ Ultimately, the corporation will fail, so that management lose their jobs and the shareholders lose their capital. ${ }^{71}$ The market for managerial talent

68. This distinction is drawn in $R$. POSNER, supra note 16 , at 302 . Anderson, supra note 16 , at $776 \mathrm{n} .111$, has criticized the characterization of laziness as inefficiency because laziness may also be a form of consumption and thus is better characterized as diversion of corporate income. While Anderson's criticism has merit, the distinction is analytically helpful and its partial inaccuracy does not change the substance of the argument.

69. The problem of inefficient production-of "shirking"-exists for all levels of supervisors, not merely senior management. But one would expect the self-interest of lower level managers to aid more senior management in policing this conduct. Lower level supervisors, interested in their own advancement, have an incentive to be sure that their supervisors are made aware of their successes and the failures of their competitors for promotion, thus reducing the cost of securing information. Fama, supra note 67, at 293. Lower level managers also monitor the performance of their supervisors: "Lower managers perceive that they can gain by stepping over shirking or less competent managers above them. Moreover, in the team or nexus of contracts view of the firm, each manager is concerned with the performance of managers above and below him since his marginal product is likely to be a positive function of theirs." Id.

70. For my purpose, the controversy over whether the product market acts as a constraint on management discretion in oligopolistic or monopolistic industries need not be resolved. Compare Jensen \& Meckling, supra note 64, at 329-30 and $R$. WINTER, supra note 16, at 20-21, with Williamson, Corporate Control and the Theory of the Firm, in ECONOMIC POLICY AND THE Regulation of CoRporate Securties 281, 294-95 (H. Manne ed. 1969). I wish to establish only that the product market operates as some constraint, not that it completely eliminates discretion.

71. E.g. , R. POSNER, supra note 16 , at $302 ;$ R. WINTER, sufra note 16 , at 18 . Indeed, the cost of failure may be far greater for management than for the stockholders. The latter, it will be recalled, are presumed to hold a diversified portfolio of securities, the value of which should not be significantly affected by events-like business failure due to the inefficiency of 
also provides incentives for management efficiency. The corporation's performance is commonly treated as a measure of a manager's skills, and hence is a central-determinant of the future value of the manager's services. ${ }^{72}$ Finally, managerial inefficiency is constrained by the capital market. A corporation's poor performance in its product market is reflected in the market price of the corporation's stock. Where poor performance is due to management inefficiency, the potential for gain exists through purchasing the corporation's shares at the depressed price and then installing efficient management. ${ }^{73}$

management-affecting only a particular firm. Nontechnical discussions of portfolio theory are contained in V. Brudney \& M. Chirelstein, Cases and Materials on Corporate FinANCE 1143-76 (2d ed. 1979) and in J. LORIE \& M. HAMILTON, supra note 14, at 171-97. A more detailed, but still accessible presentation is contained in W. SHARPE, INVESTMENTS 70-93 (1978). In contrast, the manager has invested his human capital in the firm through his employment decision, an investment which cannot easily be diversified. But of. Note, The Conflict Between Managers and Shareholders in Diversiffing Acquisitions: A Portfolio Theory Approach, 88 Y ALE L.J. 1238, 1241-44 (1979) (arguing that one motivation for conglomerate mergers is management's desire to diversify their employment "investment").

72. The role of the managerial market as a mechanism for constraining managerial discretion to deviate from profit maximization is considered in detail in Fama, supra note 67. See also R. POSNER, supra note 16, at 302; Werner, supra note 16, at 403 . As developed by Professor Fama, this mechanism operates both within the firm, powered by the ambition of lower managers, Fama, supra note 67, at 293, and through external forces such as the price of the corporation's stock as a measure of managerial talent, $i d$. at 292 . Ultimately, however, the extent of the constraint on top management depends on the extent to which top management can be policed. So long as these managers control their own tenure, the constraint imposed by a potential reduction in the market value of their services if they were forced to change jobs is reduced: "Having gained control of the board, top management may decide that collusion and expropriation of security holder wealth are better than competition among themselves." Id. at 293. Independent directors might serve to limit the extent of such collusion: "In a state of advanced evolution of the external markets that buttress the corporate firm, the outside directors are in their turn disciplined by the market for their services which prices them according to their performance as referees." Id. at 294. And, one must acknowledge, displacement of top management by independent boards of directors does seem to be occurring with increasing frequency. See Bauer, Why Big Business is Fining the Boss, N.Y. Times, March 8, 1981, $\S 6$ (Magazine), at 22. But the question remains as to what force prevents "collusion and expropriation" from circumventing market discipline on the outside directors. Fama falls back on the role of the capital markets as a mechanism which will allow the forcible displacement of unfaithful managers, something which the market for managers, even as he formulates it, will not accomplish. Fama, supra note 67, at 294-95.

73. I will have more to say about the market for corporate control in notes 84-98 info and accompanying text. The impact of capital market constraints is also felt through the product market. To the extent that the corporation's performance is reduced through ineffciency, providers of capital will require a greater return before making their capital available to the corporation. See, e.g., R. WINTER, supra note 16, at 18-28. This should result, for example, in higher borrowing costs for less efficient corporations, which should put them at a disadvantage in the product market compared to companies with more efficient management and lower capital costs. 
Thus, inefficiency may be policed before it results in business failure even if management ignores earlier signals.

Where incentive mechanisms created by one part of the corporate structure-the various markets in which the corporation and its managers function-constrain managerial discretion to perform inefficiently, one would not expect a different part of that structure to provide redundant controls. ${ }^{74}$ As we have seen, the legal elements of the corporate structure are consistent with this conclusion. The typical corporate statute assigns management responsibility to the board of directors. The business judgment rule measures the discharge of that responsibility. The rule operates to bar courts from providing additional, and unnecessary, constraints on management discretion through judicial review of operating decisions. ${ }^{75}$

The role of low-cost market mechanisms in restraining managerial discretion is more limited with respect to management's incentive to allocate to itself an excessive portion of the corporation's income. Incentives to succeed in the product market are less likely to constrain managerial self-dealing, since what is of concern is management's ability to allocate to itself income generated through successful operation of the corporation's business. Nor will the capital market provide a substantial constraint. Although a lower rate of return to shareholders may increase the corporation's cost of new equity capital by decreasing the value of the corporation's shares, this constraint operates only to the extent the corporation cannot finance its activities through retained earnings and debt. ${ }^{76}$ In any event, the cost is borne by existing shareholders through dilution of their interests. ${ }^{77}$

The managerial services market is also less likely to constrain selfdealing than to constrain inefficiency. The buyers of managers for public corporations are, realistically, other managers. ${ }^{78}$ There is no

74. This is not to argue, however, that these markets eliminate managerial inefficiency. My point is merely that the costs of mechanisms designed to further reduce the incidence of inefficiency would likely exceed the gains from the reduction. See Jensen \& Meckling, supra note 64 , at $326-28$.

75. See notes 6-16 supra and accompanying text.

76. Unless lenders believe that management's diversion of part of the corporate income stream increases the risk of business failure $-a$ non-obvious proposition since management has extra reason to keep alive the golden goose-the diversion should not affect the cost of debt.

77. R. POSNER, supra note 16, at 302; Jensen \& Meckling, supra note 64, at 312-13.

78. See, e.g., M. EISEnberg, supra note 28, at 162-69; M. MACE, Directors: MYTH AND Reality 65-68, 71 (1971); Mace, Directors: Myth and Reality-Ten Years Later, 32 Rutgers L. ReV. 293 (1979). 
reason to believe that an efficient manager's penchant for high pay or perquisites will be negatively viewed.

Thus, except for the potential constraint imposed by the market for corporate control, the market component of the corporate structure is not likely to impose substantial limits on management's ability to self-deal. In contrast to its function with respect to managerial inefficiency, the legal component of the corporate structure has a significant role in constraining management's self-dealing.

Consistent with this conclusion, the courts (and some statutes) ${ }^{79}$ require that management demonstrate the fairness of its dealings with the corporation. ${ }^{80}$ But while a judicially enforced fairness standard may reduce management discretion to self-deal in many settings, there are important situations where the potential for management's favoring itself at the expense of shareholders cannot be limited by reference to fairness. ${ }^{81}$ For example, where corporate income is diverted to acquiring new businesses rather than being distributed to the shareholders, the question of fairness, as measured by the price paid for the business, is beside the point. Judicially determining whether a particular acquisition was "fair," or whether the funds should instead have been returned to the shareholders by way of dividends, is impossible. ${ }^{82}$ And as I have argued, the same problem exists when management's self-dealing takes the form of resisting changes in corporate control. ${ }^{83}$

Thus far, the structure of the corporation-market constraints and a judicially enforced fiduciary duty-does not effectively limit management's ability to self-deal by protecting its control position. The market for corporate control is the remaining potential source of constraint. Considering the fit of this market in the corporate structure leads back to the role of tender offers and the bearing of corporate structure on the appropriateness of management opposition.

79. See text accompanying note 48 supra.

80. See notes 17-19 supra and accompanying text.

81. What goals managers pursue when given the discretion has been the subject of a substantial literature, which has recently been surveyed in Marris \& Mueller, The Corporation, Competition, and the Invisible Hand, 18 J. ECON. LrT. 32 (1980). For an early review, see Machlup, Theories of the Fim: Marginalist, Behavioral, Managerial, 57 AM. ECON. REv. 1 (1967). For my purpose, the existence of the discretion, rather than its use, is of principal interest.

82. See Brudney, Dividends, Discretion, and Disclosure, 66 VA. L. REv. 85, 103-08 (1980).

83. See notes 21-44 supra and accompanying text. 


\section{The Market for Corporate Control}

Owing to the groundbreaking work of Henry Manne, ${ }^{84}$ it is now commonly acknowledged that the market for corporate control is an important mechanism by which management's discretion to favor itself at the expense of shareholders may be constrained. ${ }^{85}$ Indeed, where that favoritism is expressed in subtle ways, the market for corporate control may be the only potentially serious force for limiting management discretion. Thus, the fit of this constraint within the legal and market structure of the corporation is of central importance.

The theory of a corporate control market posits that a decrease in corporate profits, whether because of inefficient management or because efficient but self-dealing management has diverted too much income to itself, causes the price of the corporation's stock to decline to a level consistent with the corporation's reduced profitability. This creates an opportunity for entrepreneurial profit. If shares representing control can be purchased at a price which, together with the associated transaction costs, ${ }^{86}$ is less than the shares' value follow-

84. Manne, Market for Corporale Control, supra note 23; see Manne, Cash Tender Offers for Shares-A Reply to Chaiman Cohen, 1967 Duke L.J. 231; Manne, supra note 9; Manne, Share Voling, supra note 23; Manne, supra note 12.

85. E.g. , M. EISENBERG, supra note 28, at 66-68; R. POSNER, supra note 16, at 303-05; R. WINTER, supra note 16, at 18-28; Fama, supra note 67, at 295; Hindley, Separation of Ownership and Control in the Modem Corporation, 13 J.L. \& ECON. 185 (1970); Jensen \& Meckling, supra note 64, at 294-95; Werner, supra note 16, at 403-44. Even Oliver Williamson, perhaps the most persistent critic of the significance of control market constraints on managerial discretion, concedes that some constraint is forthcoming: "[T]he question that needs to be addressed is whether . . . competition in the capital market can be reliably regarded as a substitute means of enforcing neoclassical profit maximizing behavior. Note that the issue is not whether competition in the capital market has a 'tendency' to promote behavior along profit maximizing lines; no one appears to deny the existence of such effects. The essential question is the matter of degree." Williamson, supra note 70, at 296.

86. Transaction costs in takeovers can take a variety of forms: 1) information-search costs incurred by the acquiring corporation in order to identify an attractive target. See, e.g., Grossman \& Hart, Takeover Bids, The Free Rider Problem, and the Theory of the Corporation, 11 BELL J. ECON. 42, 57-58 (1980); Jarrell \& Bradley, The Economic Effects of Federal and State Regulations of Cash Tender Offers, 23 J.L. \& ECON. 371 (1980); 2) administrative-making even an uncontested tender offer requires such elements as an information agent, forwarding agents, and depositories. See, e.g., 1 M. LiPTON \& E. STEINBERGER, supra note 2, at 11-12; 3) regulatoryeven an uncontested tender offer poses the expense of compliance with the filing, waiting period, or other requirements of one or more regulatory systems. First, the filing and disclosure requirements of the Williams Act, 15 U.S.C. $\$ \S 78 l-78 \mathrm{n}$ (1976), must be satisfied. See, c.g. , 1 M. LIPTON \& E. STEINBERGER, supra note 2, at 173-221. Second, if the acquisition is of sufficient size, the filing and waiting period requirements of Title II, "Premerger Notification," of the Hart-Scott-Rodino Antitrust Improvements Act of 1976, 15 U.S.C. § 18a (1976), must be met. See generally S. AxInN, B. Fogg \& N. STOLL, ACQUisitions UNDER THE HARTSCOTT-RODINo ANTITRUST IMPROVEMENTS ACT (1979). Third, the transaction may fall 
ing displacement of existing management, then everyone-other than the management to be displaced-benefits from the transaction. Selling shareholders receive more for their stock than its value under previous management; new management receives an entrepreneurial reward through the increased value of acquired shares; and society benefits from more efficiently used resources. ${ }^{87}$

Two important conditions are necessary for this happy concurrence of results. First, the market price of the corporation's stock must accurately reflect incumbent management's inefficiency or greed. Second, there must be mechanisms available for displacing incumbent management. While little debate remains concerning satisfaction of the stock market condition, ${ }^{88}$ major difficulties remain concerning the availability of displacement mechanisms.

Four general mechanisms for displacing incumbent management are possible under modern corporate statutes: a merger, a sale of substantially all of the corporation's assets, a proxy fight, and a tender offer. The availability of each in the face of resistance by in-

within the requirements of one of the 34 state tender offer laws. The variety of approaches reflected in these statutes is surveyed in Bartells, State Takeover Statules: $A$ Survey, in 1 NINTH ANNUAL Institute ON Securities Regulation 341 (1977). The constitutionality of state efforts to regulate tender offers is doubtful, and the three courts of appeals which have faced the issue found the state statute before them unconstitutional. Kennecott Corp. v. Smith, [1980 Transfer Binder] FED. SEC. L. ReP. (CCH) If 97,731 (3d Cir. 1980) (New Jersey); Mite Corp. v. Dixon, 633 F.2d 486 (7th Cir. 1980), prob. juris. noted sub nom. Edgar v. Mite Corp., 49 U.S.L.W. 3824 (1981) (Illinois); Great W. United Corp. v. Kidwell, 577 F.2d 1256 (5th Cir. 1978), rev'd on other grounds sub nom. Leroy v. Great W. United Corp., 443 U.S. 173 (1979) (Utah). Finally, if the target is also subject to regulation by such agencies as the Interstate Commerce Commission, Federal Communications Commission, or Federal Maritime Commission, a change in control may require prior administrative approval in order to avoid loss of licenses or permits. See, e.g., A. FleISCHER, supra note 2, at 24-11 to -27; 4) defensivetarget management opposition may also impose substantial costs. For example, the general counsel of Mead Corp. predicted that the fees of only the principal law firm in its successful resistance of an Occidental Petroleum exchange offer could be as much as three million dollars. The Flom Firm Takes Over as Top Money Maker in '78, Am. Law., Feb. 1979, at 1, col. 1, and at 13 , col. 2. It was reported that the costs of that contest to both sides totalled some $\$ 15$ million, and that the total fees, for lawyers, accountants, investment bankers, proxy solicitors, and public relations professionals, incurred by the three parties in the battle between McDermott, Inc. and Wheelabrator-Frye, Inc. for Pullman, Inc. were some $\$ 17$ million. Outside Professionals Play an Increasing Role in Corporate Takeovers, Wall St. J., Dec. 2, 1980, at 1, col. 6.

A recent empirical study has estimated that transaction costs may amount to at least $13 \%$ of the post-offer market price of the target's shares. Smiley, Tender Offers, Transactions Costs and the Theory of the Firm, 22 REV. ECON. \& STAT. 22 (1976); accord, O. Williamson, supra note 38 , at 100 (estimate of $10-25 \%$ ).

87. See notes $84-85$ supra.

88. See note 14 supra. 
cumbent management differs substantially, ${ }^{89}$ a fact crucial to the operation of the market for corporate control since, in that market, resistance exists by definition.

Under most corporation statutes, merger or sale of assets is impossible without incumbent management's cooperation. Both methods require shareholder approval, but shareholders cannot consider the proposal unless the board of directors first approves it. ${ }^{90}$ If incumbent management opposes the transaction, the shareholders will have no opportunity to consider it. ${ }^{91}$

Corporate law and economics combine to make the proxy fight an unattractive displacement mechanism. As a practical matter, incumbent management may use corporate resources to resist the challenger's candidacy. ${ }^{92}$ The challenger, however, must use its own funds, which are unlikely to be reimbursed if the challenge fails. ${ }^{93}$ Moreover, although the proxy contest campaign costs are largely independent of the number of shares owned by the challenger, the challenger's expected return on its investment seemingly is dependent on share ownership; only shareholders will receive benefits resulting from displacement. Thus, in addition to the free rider problem, ${ }^{94}$ return on the challenger's investment is likely to be greater on funds spent to acquire shares (and votes) than on the costs of the proxy contest itself. This counsels in favor of the remaining displacement mechanism-the tender offer.

If incumbent management has complete control over mergers and sales of assets, and if proxy contests are economically unattractive to potential challengers, ${ }^{95}$ then the tender offer assumes a critical

89. For discussion of the factors other than management resistance bearing on the choice among acquisition techniques, see, c.g., 1 Business ACQUisitions: PlanNing AND Practice (J. Herz \& C. Baller eds. 1971); B. Fox \& E. FoX, Corporate Aceuisitions AND Mergers $\S \S 23.01-27.09$ (1980); J. Freund, ANATOMy OF a MERGER: STRATEgies AND TECHNIQUES FOR NEgOTIATING CORPORATE ACQUisitions 75-138 (1975).

90. See, e.g., CAL. CORP. CODE $\S \S 1101$ (merger), 1001 (sale of assets) (West 1977 \& Supp. 1981); DEL. CODE ANN. tit. 8, §§ 251 (merger), 271 (sale of assets) (1975 \& Supp. 1980); N.Y. Bus. CoRP. LAW $\S \S 902$ (merger), 909 (sale of assets) (McKinney 1963 \& Supp. 1980 81); ABA-ALI MODEL Bus. CORP. ACT ANN. 2D $\$ \$ 71$ (merger), 79 (sale of assets) (1971).

91. See, e.g., Clark, supra note 57, at 788-89; Dodd, Merger Proposals, Management Discretion and Slockholder Wealth, 8 J. FIN. ECON. 105, $105-06$ (1980); Manne, Share Voting, supra note 23, at $1437-38$.

92. E.g. , Rosenfeld v. Fairchild Engine \& Airplane Corp., 309 N.Y. 168, 128 N.E.2d 291 (1955); see note 32 supra. See generally E. Aranow \& H. EINHORn, Proxy Contests For Corporate Control 541-68 (2d ed. 1968); M. EISENBERG, supra note 28, at 121-27.

93. E. ARANOw \& H. EINHORN, supra note 92, at 569-81.

94. See Clark, supra note 57, at 783-84.

95. Casual evidence supports the conclusion that a proxy contest is an uneconomic 
role in the corporate structure. The market for corporate control is the principal constraint on management self-dealing in important situations, and the tender offer is the only displacement mechanism which has the potential to effectuate that constraint. Further, the market for corporate control, effectuated by tender offers, is also an important pre-bankruptcy constraint on management inefficiency. To the extent that the business judgment rule presupposes effective nonlegal constraints on management decisions, ${ }^{96}$ it is inconsistent with management control over tender offers.

If management can adopt defensive tactics which prevent shareholder decisions to accept a tender offer, the results are predictable. An offer will be made only if the perceived value of the corporation following displacement of incumbent management exceeds the share

method of displacing management. Despite extensive shareholder litigation, the managements of Marshall Field, Panter v. Marshall Field \& Co., 486 F. Supp. 1168 (N.D. Ill. 1980), affd, Nos. 80-1375, 80-1389 (7th Cir. Apr. 2, 1981), Gerber Products, Berman v. Gerber Prods. Co., 454 F. Supp. 1310 (W.D. Mich. 1978), and McGraw-Hill, Lewis v. McGraw, 619 F.2d 192 (2d Cir. 1980), cert. denied, 101 S. Ct. 354 (1980), are still in place. No proxy contests have been launched to displace them. This apparent shareholder preference for class action litigation over proxy contests seems quite sensible. In contrast to the free rider problem inherent in the proxy fight, the availability of the contingent fee in class action litigation eliminates the need for an individual shareholder to advance the funds for the contest, and compensation of the lawyer from a common fund eliminates the free rider problem. In granting fee awards to class action plaintiffs' lawyers, courts expressly consider the "riskiness" of the case as a factor in determining the size of the award. See, e.g., Valente v. Pepsico, [1979 Transfer Binder] Fed. SEc. L. REP. (CCH) If 96,921, at 95,862 (D. Del. 1979) (citations omitted): "After careful consideration, this court also finds that the [fee determined by multiplying hours worked by a reasonable hourly rate] must be substantially increased, first because of the contingent nature of success. In pursuing the development of this case, plaintiffs and their attorneys carried a heavy burden and assumed a significant risk. Since no governmental investigation or other court action preceded this case, it was begun and pursued without substantial assurance as to what the evidence might prove. Despite this uncertainty, plaintiffs' attorneys undertook substantial discovery . . . . While these investigations apparently yielded helpful evidence, the results could have been otherwise; plaintiffs might have been forced to abandon this case, leaving their attorneys without compensation.

“. . . [P]laintiffs' attorneys also assumed the risk of adverse developments in the unsettled law of securities regulation . . . . Thus, plaintiffs' attorneys undertook a substantial risk of adverse legal rulings. . . ."

Indeed, a plaintiffs' lawyer functions to some extent as a risk arbitrageur. The lawyer will expend funds on the lawsuit as long as there is sufficient likelihood of liability that potential fees (which take risk into account), discounted by time and the potential of nonliability, exceed the lawyer's opportunity cost. See Clark, supra note 57, at 785-87.

Proxy contests cannot be dismissed entirely, however. They do in fact occur, and management does occasionally lose. The occasional occurrence of a proxy fight may be accounted for by the lower capital cost of the transaction. While a tender offer presents a more attractive investment, it is available only if the additional funds necessary to purchase the shares can be obtained.

96. See texts accompanying notes 14-16, 73-74 supra. 
price offered plus the transaction costs associated with acquiring the shares. ${ }^{97}$ If incumbent management can increase the transaction costs associated with a tender offer, the incentive to make that offer and the constraint imposed by the potential that an offer will be made are decreased, and incumbent management's discretion correspondingly increased. ${ }^{98}$ Thus, the corporate structure requires that tender offerors have unrestricted access to target shareholders.

\section{The General Principle: Shareholders Must Make the Decision}

The argument thus far presented is that other elements of the structure of the corporation, having statutory, judicial and market components, serve to constrain the managerial discretion unavoidably resulting from the modern corporation's need for specialized managerial skills and capital. The tender offer is the critical mechanism through which the corporate structure imposes constraints on certain forms of managerial self-dealing. It is in this context that a structural approach to corporate law considers the validity of defensive tactics.

The result of management adopting successful defensive tactics is to make impossible a tender offer which management has not blessed. For example, the postoffer acquisition by the target of a business which creates an antitrust barrier to the offer ${ }^{99}$ causes access to shareholders through a tender offer to be conditioned in the same manner that the corporate statute conditions access to shareholders in a merger or sale of assets. Absent approval of incumbent management, a tender offer, like a merger or sale of assets, is impossible.

This result, however, is flatly inconsistent with the structure of the corporation. The market for corporate control is crucial to the corporate structure because neither other markets nor a fiduciary "fairness" standard effectively constrains some forms of management self-dealing. Moreover, the control market allows a final constraint on management inefficiency short of business failure. In turn, the

97. See note 86 supra.

98. For example, suppose an offeror believes that a potential target would be worth $\$ 50$ per share if the offeror could secure control. If the transaction costs associated with securing control were $\$ 5$ per share, the offer would be worthwhile at any price below $\$ 45$ per share. If transaction costs increased to $\$ 15$ per share because of target management action, then the market value of the shares would have to drop below $\$ 35$ per share before the offer would be worthwhile to the offeror. Management's discretion to favor itself or manage inefficiently would increase by an amount with a capitalized value of $\$ 10$ per share. See Smiley, supra note 86 , at 24-25.

99. The extensive use of this tactic by Marshall Field \& Co. is chronicled in Panter v. Marshall Field \& Co., Nos. 80-1375, 80-1389, slip op. at 3-5, 8-9 (7th Cir. Apr. 2, 1981). 
tender offer is crucial because no other displacement mechanism is available without management cooperation. If management can use defensive tactics to obtain a degree of control over tender offers similar to that given it over mergers and sales of assets, then the corporate structure is fundamentally altered in a fashion which allows management effective monopoly power over corporate control. Rather than displacement occurring when the gains from displacement (the benefits of synergy or the elimination of inefficiency or self-dealing) exceed the price to be paid (including transaction costs), transfer of control will occur only when the benefits to incumbent management from the transaction exceed the capitalized value to management of its existing discretion. In short, defensive tactics, if successful, circumvent the mechanism by which the corporate structure constrains managerial discretion and, therefore, are improper.

The structural argument establishing the invalidity of defensive tactics, generally based on the interplay between statute, courts, and markets, is perfectly consistent with a construction of the statutory terms dealing directly with displacement mechanisms. Not surprisingly, this construction is based on analysis of the relationships created by the statute itself; coming full circle, this is precisely the form of argument by which the courts initially developed the fiduciary duty concept. ${ }^{100}$

Corporate statutes properly place the ultimate responsibility for evaluating proposals for merger or sale of assets with management. These complicated transactions require substantial time investments for shareholders to understand them. ${ }^{101}$ Assuming loyal management, a rational shareholder would not invest time considering a merger or sale of assets unless management, through application of

100. See notes 45-54 supra and accompanying text.

101. Where the transaction involves the issuance of the offeror's securities, the offer must be registered with the Securities and Exchange Commission pursuant to the Securities Act of 1933 unless an exemption from registration is available. See generally $R$. JENNiNGS \& H. Marsh, Securities Regulation: Cases and Materials 464-95 (4th ed. 1977). Until recently, such a transaction would be registered on Form S-14, 17 C.F.R. $\S 239.23$ (1980), which has been described as generating "some of the longest and most complex disclosure documents presented to investors," with an average length of 110 pages, and some exceeding 200 pages. House COMm. ON INTERSTATE AND Foreign COMMERCE, 95Th CONG., IST SESS., REPORT Of THE AdVisory COMM. ON CORPORATE Disclosure to the Securities and Exchange Commission 440 (Comm. Print 1977) [hereinafter cited as RePORT ON Corporate Disclosure]. The SEC has recently adopted Form S-15, 45 Fed. Reg. 63,647 (1980) (to be codified in 17 C.F.R. $\S 239.29$ ), intended to be an abbreviated alternative to Form S-14, for use in a limited range of acquisition transactions. See generally Eppler, Short Form Registration in Business Combination Transactions-Form S-15, in PRACTISING LaW INSTItUTE, ACQUisitions AND Mergers: Tactics AND TechniQues 87 (1980). 
its specialized skills, had already approved it. The problem is ensuring, within reasonable limits, that management's determination-for example, to reject an offer-is motivated by the shareholders', rather than management's, best interests. And it was precisely the difficulty of making such a determination which forced courts to sidestep the problem by applying the business judgment rule to management's fiduciary role in changes of control. ${ }^{102}$ The solution is the check and balance of the tender offer. If management, in rejecting merger or sale of assets proposals, gives priority to its own interests rather than those of the shareholders, the spurned suitor can make a tender offer to the shareholders. ${ }^{103}$ Should management become too recalcitrant, an alternative is available.

This system of check and balance, of management control of some mechanisms by which control may be shifted but with unfettered access to shareholders through another, is precisely the structure reflected in the typical corporation statute. While control of the merger and sale of asset mechanisms is firmly ensconced in management, the tender offer mechanism generally is not even mentioned in the statute, let alone placed within management's control. ${ }^{104}$ Thus,

102. See notes 25-28 supra and accompanying text.

103. Where management favors itself by accepting an offer-perhaps because of favorable side payments in the form of employment contracts or stock options-the statute provides an explicit, if in practice illusory, check through the statutory requirement of shareholder approval. See note 90 supra and accompanying text. The constraint of shareholder approval, however, is buttressed by the operation of the market for corporate control. Between the public announcement of board of director approval of the transaction and the date of the shareholder meeting, competing offers-via tender offers-may be made if the transaction negotiated by management was too favorable to the offeror or to management.

104. Where the tender offer is explicitly mentioned, it is in an effort to provide a statutory solution to the de facto merger problem. For example, CAL. CORP. CODE $\S 181$ (West 1977) defines three types of reorganizations, including an "exchange reorganization" which amounts to an acquisition by means of a tender offer where the consideration is the offeror's stock. Section 1201 requires a vote of the shareholders of the offeror if, following the transaction, these shareholders will own shares of the offeror representing less than five-sixths of the voting power. No role at all is created for the target board. See generally Small, Corporate Combinations Under the New Califormia General Corporation Law, 23 U.C.L.A. L. REv. 1190 (1976).

That the statute does not assign management a role in traditional tender offers is underscored by the addition in 1976 of Model Business Corporation Act $\S 72 \mathrm{~A}$. ABA-ALI MODEL Bus. CORP. ACT ANN. 2D § 72A (Supp. 1977). This section creates a mechanism by which an exchange offer can be made binding on target shareholders if both the board of directors and the shareholders approve the transaction by the same procedures required for mergers and sales of assets. While management is given a role where the transaction is made binding, the statute expressly preserves the option of a traditional tender offer, and in that setting no role is accorded target management. Only a few jurisdictions have followed the Model Act in adopting such a provision. See W. Cary \& M. Eisenberg, Cases and Materials on CorPORATIONS 1501 (5th ed. 1980). 
to reiterate my basic point from a somewhat different perspective, all components of the structure of the modern corporation-market, judicial, and statutory - combine to establish a critical role for the tender offer: as the principal displacement mechanism by which the capital market may police the performance of management and thereby justify the central role accorded management in other displacement mechanisms. Defensive tactics, because they alter the allocation of tender offer responsibility between management and shareholders contemplated by this structure, are inappropriate.

\section{Responses to Arguments for Management Discretion TO Block a TENDER OFFER}

There has been no shortage of defenders of a management role far broader than that assigned by my structural approach. The arguments offered by management's champions all seek to justify allowing management to prevent shareholders, under particular circumstances, from displacing management by tendering their shares. The common thread joining the arguments is the unlimited discretion accorded management to identify the circumstances.

\section{A. Functional Equivalence to Other Acquisition Techniques}

The most common argument supporting managerial discretion to block a tender offer asserts that a tender offer is functionally no different from any other acquisition technique. ${ }^{105}$ If management has effectively complete discretion over whether shareholders will be given the opportunity to vote on a merger or sale of assets, then it should have a comparable role with respect to tender offers. Certainly, the argument continues, the mere form chosen for substantively equivalent transactions should not determine management's role. ${ }^{106}$

105. See, e.g., Herzel, Schmidt \& Davis, supra note 21, at 159; Lipton, Takeover Bids in the Target's Boardroom, 35 Bus. LAw. 101, 104, 116 (1979); Pearlmutter, Shareholders vs. The Corporation, N.Y. Times, Mar. 9, 1980, §3, at 18, col. 3 (Mr. Pearlmutter is a general partner of Lazard Freres \& Co., a major investment banking firm); Steinbrink, Management's Response 10 The Takeover Allempl, 28 CASE W. RES. L. REv. 882, 892 (1978). When the transaction is friendly-i.e., target management has approved the acquisition-a tender offer is the equivalent of the alternative acquisition techniques and the choice among them is made on the basis of criteria other than the need to avoid a management veto.

106. Some commentators have taken the point a good deal further by pointing to the statutory award of the duty to manage the corporation to the board of directors, and then arguing that a tender offer presents a policy decision no different from others-like plant investment-which no one disputes should be made solely by management. E.g., Pearlmutter, supra note 105 , at 18 , col. 3 ("Is a takeover bid of such a different nature from other 
The argument extrapolates the typical statutory terms dealing with mergers and asset sales to a form of transaction-the tender offer-rarely mentioned in the typical statute. ${ }^{107}$ A nonstructural response is that a technical construction of the statute-contrasting the pivotal role assigned management with respect to mergers and asset sales with the absence of any statutory role with respect to tender offers-favors a more limited tender offer role for management. The statutory silence regarding tender offers may simply reflect a legislative assumption that free alienation of property is the norm, so that management's affirmative role in mergers and asset sales needs to be stated, while its nonrole in tender offers need not. ${ }^{108}$ And while functional equivalence advocates argue that the earlier statutes were silent because they were adopted prior to the time when hostile tender offers became popular acquisition techniques, ${ }^{109}$ even a vigorous proponent of management discretion acknowledges that "continuation of [the statutory silence] in recently adopted statutes is disquieting." 110

One need not, however, limit response to the language of the statute. Under a structural view, functional equivalence among acquisition techniques is important, but this view favors a nonequivalent, much more limited, role for management in tender offers. The management monopoly of the market for corporate control which would

important business decisions, such as hiring a new chief executive officer or approving a large capital expenditure program, that the shareholders should decide the issue themselves?'); see Lipton, supra note 105 , at 120.

The broader position proves too much. The basic equivalence argument asserts that a tender offer is the same as a merger or sale of assets. But in those decisions, the typical corporation statute clearly gives the shareholders a role different from that given with respect to other "important" policy decisions: Actions which involve direct sales of the corporation, like mergers and sales of assets, require shareholder approval, while the supposedly analogous policy decisions do not. See M. EISENBERG, supra note 28, at 213-51; Carney, Fundamental Corporate Changes, Minority Shareholders, and Business Purposes, 1980 AM. B. Foundation REs. J. 69. Therefore, the analogy between takeover bids and other policy decisions, given the equivalence argument, should also apply to mergers and sales of assets, which is inconsistent with the structure of the statute.

107. See note 104 supra and accompanying text.

108. See Ballantine on CoRporations 775-77 (rev. ed. 1946); M. Eisenberg, supra note 28, at 239; McNulty, Corporations and the Intertemporal Confict of Laws, 55 CALIF. L. REV. 12 (1967).

109. E.g., Steinbrink, supra note 105, at 889. No authority is offered for the assertion. Moreover, the corporate statutes which do cover an exchange offer, such as GAL. CORP. CODE $\S \S 151,1201$ (West 1977 \& Supp. 1981) and OHIo Rev. Code ANN. $\S$ 1701.01(R)-(T), .83(A), .84(D) (Page 1978), either treat the de facto merger problem or create a share exchange mechanism, see note 104 supra, but still do not grant directors an express tender offer role.

110. Steinbrink, supra note 105 , at 890 (citations omitted). 
result from extending management autonomy to tender offers eliminates the discipline imposed on management by that same market. Restricting management's role in a tender offer does not deny the value of management's expertise in evaluating and negotiating complex corporate transactions, but rather validates the unfettered discretion given management with respect to mergers and sales of assets.

For this purpose, the crucial distinction is not between different acquisition techniques, but between negotiated and hostile transactions. In a negotiated transaction, the acquisition terms result from bargaining between the offeror and target management, and shareholders benefit from management's skill and experience. The problem, however, is that target management may elect not to negotiate, or not to negotiate in good faith. Management's interest in remaining in office creates a conflict which the traditional standards of care and loyalty are incapable of policing. In this setting, the tender offer provides a self-executing check on management's discharge of its responsibility as holder of primary control over the acquisition process. "If negotiations break down, it is still possible for the acquiring company or someone else to go forward with a tender offer. The existence of this safety valve against the directors' conflict of interest is an important justification for giving the directors unfettered discretion in the process of negotiating acquisitions." 111

Moreover, offerors should not prefer to use a tender offer to sidestep target management and thereby deprive target shareholders of management's guidance and bargaining. The negotiation process typically involves transferring to the offeror substantial amounts of nonpublic information concerning the target. ${ }^{112}$ This information

111. Herzel, Schmidt \& Davis, supra note 21, at 158. The use of differential levels of regulation for substantively similar, indeed competing, activities has been advocated in other areas. See Bollinger, Freedom of the Press and Public Access: Toward a Theory of Partial Regulation of the Mass Media, $75 \mathrm{MicH}$. L. REv. 1 (1976) (explanation for differential regulation of public access to electronic media and print media).

112. While substantial consideration will have been given to the selection of an acquisition candidate prior to the point at which actual negotiations begin, it is commonly recognized that the negotiation process itself generates large amounts of information concerning the target which is available through no other source. See, e.g. , J. FREUND, supra note 89, at 230-31; J. McGaffey, Buying, Selling, and Merging Businesses 13-32 (1979). Consider, for example, the process of negotiating the representations and warranties contained in a typical acquisition agreement. The target will be asked to warrant, inter alia, the accuracy of financial statements and the absence of significant change since the date of the most recent audited statement; the absence of any liabilities for taxes or other matters not disclosed in the agreement including, most importantly, the absence of contingent liabilities; the condition of various assets believed to be of importance to the operation of the target's business; the existence of litigation against the target, whether actual or threatened; and the extent to which 
reduces uncertainty about the future return on the acquisition and hence increases the value of the investment to the offeror. ${ }^{13}$ Even though target management may drive a hard bargain on behalf of the shareholders, the offeror has an incentive to negotiate, because resort to a hostile tender offer eliminates access to valuable information. ${ }^{114}$

various elements of the target's work force are unionized or with respect to which organization efforts are underway. See, e.g. , B. Fox \& E. Fox, supra note 89, \$§ 29.21-.30; J. Freund, supra note 89, at 248-83; J. MCGAFFNEY, supra, at 37-41. Freund, a prominent practitioner in the acquisition area, stresses the information-producing role of such contractual provisions and the negotiation process generally: "There are no known statistics on the subject, but I'm willing to bet my briefcase that lawyers spend more time negotiating 'Representations of the Seller' than any other single article in the typical acquisition agreement. . . .

"From the purchaser's viewpoint, representations serve at least three distinct, although overlapping, purposes. First, they are useful as a device to obtain the maximum degree of disclosure about the acquired business prior to the purchaser undertaking a binding commitment to make the acquisition. In other words, representations constitute a systematic smokeout of the data about the seller which the buyer feels is important. . . .

". . . This focusing aspect of representations can often alert the purchaser to questiona. ble areas for more detailed investigation, and may even provide ammunition for use in renegotiating the price or other terms of the deal.

"The second general purpose of representations, from the purchaser's viewpoint, is to set the stage for the purchaser to walk away from the deal if the facts develop that make it unwise to consummate the acquisition. Although in most cases the purchaser has been able to make a preliminary investigation prior to signing the agreement and has relied on certain data supplied to him by the seller, purchaser's defatitive investigation-the opening up of all seller's doors and drawers-usually takes place after the agreement has been signed." J. FREUND, supra note 89 , at 229-31 (emphasis in the original).

A similar point was made recently by the investment banker for St. Joe Minerals Corp. in explaining Seagram Co.'s loss to Fluor Corp., the white knight, in the contest for St. Joe: “Seagram 'underbid' for St. Joe because the Montreal-based distiller apparently had access only to public information on St. Joe's asset value and earning power. 'Seagram was fighting from the outside. It's like a guy fighting blind against a guy with clear vision.' "Seagrams Ends 82.13 Billion Bid for St. Joe, Wall St. J., Apr. 8, 1981, at 3, col. 1.

113. Assuming the offeror is risk-averse, the additional information can increase the value of the acquisition even if it does not affect the expected return on the investment. See W. Sharpe, Portfolio Theory and Capital Markets 20-33 (1970); Modigliani \& Pogue, An Introduction to Risk and Retum, 30 Fin. ANALysts J. 68 (1974). Moreover, because the information disclosed may eliminate some risks which the offeror had considered in determining an initial offering price, such as particular contingent liabilities, or may disclose assets, such as favorable lease renewal terms, of which the offeror had not known, the expected return on the transaction may increase as well.

114. Existing empirical data provide indirect support for the information value of the negotiation process. Dodd, supra note 91 , at 105 , compared the market response to the cancellation of previously announced nonhostile acquisitions when the cancellation was due to target management veto and when the cancellation was due to the offeror backing away from the transaction. When management vetoed the deal, the market price of the target shares, although it dropped from the offer price, remained some $10 \%$ above the pre-announcement price. Id. at 131. When the transaction was terminated by the offeror, the market value of the target shares dropped, on average, to their pre-announcement price. Id. This suggests 
The functional equivalence argument thus provides no support for allowing target management to interfere with shareholder access to tender offers. Quite the contrary, equivalence reinforces the need to restrict management's role in tender offers as a check on management conduct in the acquisition process generally.

\section{B. The Irrelevance of Inefficiency}

A second argument offered in support of management discretion to block tender offers simply denies that current tender offer practice operates to discipline inefficient or self-dealing management:

[One] would be hard-pressed to argue that the companies involved in the most prominent hostile takeovers in 1976 and 1977 were managed by inefficient executives. . . . [W] [Wile meaningful data has not been collected and made generally available, the common belief is that the typical target companies today are successful participants in their particular fields and are managed by able personnel. ${ }^{115}$

There is by now a fair amount of empirical research measuring the performance of target companies and their securities in various periods prior to their becoming the subject of a tender offer. These studies generally conclude that the stock of target companies significantly underperforms the market during the pre-tender period. ${ }^{116}$ Indeed, one study concludes that not only are target companies underperformers-to the extent of some $50 \%$ of potential value over a relatively short period of time--but that much of the loss due to un-

that the market interprets offeror termination as signalling the discovery of negative information concerning the target during the negotiating process.

115. Steinbrink, supra note 105, at 886-87. See Troubh, Characteristics of Target Companies, 32 Bus. LAw. 1301, 1302 (1977); H. Williams, Tender Offers and the Corporate Director, Address before the Seventh Annual Securities Regulation Institute, in San Diego, Cal. Jan. 17, 1980, reprinted in [1979-1980 Transfer Binder] FED. SEC. L. REP. (CCH) I 82,445, at 82,876 .

116. Dodd, supra note 91; Dodd, Company Takeovers and the Australian Equity Market, 1 Austl. J. MgmT. 15 (1976); Dodd \& Ruback, Tender Offers and Stockholder Retums, 5 J. Fin. ECON. 351 (1977); Hindley, supra note 85; Kummer \& Hoffmeister, Valuation Consequences of Cash Tender Offers and Stockholder Returns, 33 J. Fin. 505, 509 (1978); Langetieg, An Application of a Three-Factor Performance Index to Stockholder Gains from Merger, 6 J. Fin. EcoN. 365 (1978); Smiley, supra note 86. A recent commentator has summarized his survey of these and other studies as follows: "These results present a fairly consistent pattern. Acquired firms perform poorly before acquisition and gain significantly upon acquisition. . . . These results . . . show that acquired firms typically benefit from being acquired because their performance prior to the merger was below average and was improved by the acquisition. This confirms that the corporate merger is indeed a device for transferring assets out of the hands of less competent managers into the hands of more competent ones . . . ." Asquith, 'Unpublished' Paper, excerpted in Economics of CoRporation LaW and Securities Regulation 229-31 (R. Posner \& K. Scott eds. 1980). 
derperformance is irreversible even after new management is installed. ${ }^{117}$

It is unnecessary, however, to rest the entire response on empirical measures of inefficiency. A target company may have greater value to the acquirer than as an independent entity for reasons quite distinct from target management's lack of skills. For example, a company with underutilized production capacity that acquires a competitor may reduce costs by spreading overhead over a larger volume in a manner not available to either company alone. Synergythe idea that operational or financial economies of scale may result in a value for the combined entities greater than the sum of their independent values-explains some acquisitions in a fashion which expands the concept of inefficiency beyond that acknowledged by the proponents of managerial discretion. ${ }^{118}$ Target management may be inefficient because they lack the skills or inclination to effectively manage their company; target management may also be "inefficient" because the company they manage lacks the business opportunities or financial strength necessary to improve its return on invested capital. Companies inefficient in this sense may, for a significant period of time, nonetheless remain "successful participants in their particular fields." 119

Moreover, even where the proposed transaction may seem to yield no social gains, the absence of target company inefficiency does not justify target management discretion to block a tender offer. For

117. Smiley, supra note 86, at 26.

118. See, e.g., P. Steiner, Mergers 30-37 (1975); J. Van Horne, Financlal ManAGEMENT AND Policy 630 (4th ed. 1977); Salter \& Weinhold, Diversification Via Acquisition: Creating Value, HARv. Bus. REv. July-Aug. 1978, at 166. The opportunity for operational synergy results from possible sharing of product distribution systems or the elimination of duplicative facilities. See, e.g. , P. STEINER, supra, at 47-74; Alberts, The Profitability of Growth, in THE CORPORATE MERGER 247-62 (W. Alberts \& J. Segall eds. 1966). The opportunity for financial synergy results from the possible increased financial strength of the combined entity and the opportunity for transfer of working capital between divisions in preference to outside financing. See, e.g., Scott, On the Theory of Conglomerale Mergers, 32 J. Fin. 1235 (1977); Salter \& Weinhold, supra; $c f$. O. Williamson, supra note 38 , at 109-66 (describing advantages of multidivision form of corporate organization).

119. Steinbrink, supra note 105 , at 887 . Discussions of managerial inefficiency in the context of the market for corporate control usually assume that the problem is personal to the particular managers: They simply lack the intelligence or skills to run the target company as well as alternative managers. For my purpose here, the broader concept of inefficiency described in the text is more helpful, since the market for corporate control facilitates provision of business opportunities or financial resources to the target just as it facilitates provision of more "efficient"-as narrowly defined-management. Where necessary, however, I will separate this broad "inefficiency" into personal inefficiency and "synergy" components. See notes 188-98 infra and accompanying text. 
example, some argue that acquisitions motivated purely by a desire for diversification are unlikely to benefit the shareholders of the acquiring corporation. ${ }^{120}$ Noting that the price-earnings ratios of most conglomerates trail the market as a whole, commentators claim that the stock market does not value reduction in investment risk resulting from diversification because individual shareholders can eliminate that risk through diversifying their own portfolios without having to pay the premium reflected in a typical acquisition. ${ }^{121}$

Yet the potential inefficiency of the transaction-in contrast to the inefficiency of the target company-does not justify allowing target management to block shareholder access to tender offers. The argument against such mergers is not that target shareholders are injured by the transaction, but that shareholders of the acquiring corporation are injured because of the benefit given target shareholders. ${ }^{122}$ For the target shareholders the operative concept remains the Fundamental Theorem of Exchange: that "voluntary trade is mutually beneficial."123 As for protecting shareholders of the offeror, the market also restricts the ability of acquiring company management to manage inefficiently. ${ }^{124}$ Target management is an unlikely substitute for market discipline as a means of constraining offeror management.

I do not argue that there is no cause for concern over the pace of acquisitions, principally by means of tender offers, in recent years. Harold Williams has recently argued that the acquisition phenomenon diverts investment resources from more socially productive uses. ${ }^{125}$ However, it seems highly unlikely that self-interested resist-

120. See, e.g. , G. BENTSEN, supra note 3, at 31-33; H. SALTER \& W. WeInHold, DiverSIFICATION THROUGH ACQUiSITION 41-46 (1980); Levy \& Sarnat, Diversification, Portfolio Analysis and the Uneasy Case for Conglomerate Mergers, 25 J. Fin. 795 (1970); Mason \& Goudzwaard, Performance of Conglomerate Firms: A Portfolio Approach, 31 J. FIN. 39 (1976); Scott, supra note 118.

121. Mason \& Goudzwaard, supra note 120 (comparing performance of conglomerate firms with that of diversified portfolios); Salter \& Weinhold, supra note 118, at 167-68.

122. See generally Note, supra note 71 .

123. J. Hirshleifer, Price Theory and Applications 164 (1976).

124. There is increasing evidence that market disfavor of wide diversification is causing conglomerates to shed previously acquired businesses. See, e.g. , G. BENTSEN, supra note 3, at 32-33; H. SALTER \& W. WEINHOLD, supra note 120, at 17 ("In 1976 divestitures involved over half of all acquisitions versus approximately 10 percent in the 1960's."); Lohr, Slimming Down: The GAF Case, N.Y. Times, Jan. 12, 1981, § 3, at 1, col. 1.

125. H. Williams, supra note 115 , at 82,877 ("In the last five years, I would estimate that $\$ 100$ billion of corporate cash resources-resources which could have been devoted to new production and employment opportunities-have been diverted to rearranging the ownership of existing corporate assets through tender offers alone. These are reserves that do not fow back as new capacity, improvements in productivity, new products or new jobs."). Chairman Williams does not address the question of what happens to the resources returned to target 
ance to acquisitions by target management will increase net "productive" investment by eliminating one alternative use for corporate funds. The market for capital investment is highly competitive; a preference by some firms at certain times for investment in acquisitions rather than internal expansion likely results from real economic forces rather than the degree of discretion accorded target management. ${ }^{126}$ Indeed, Williams also points to regulation and prompt competitive response to new products as factors which "encourage the search for takeover targets rather than for capital spending, product development and innovation opportunities."127 Such major macroeconomic problems are unlikely to be cured by increased discretion on the part of target management. Efforts to correct misincentives for capital investment created by governmental regulation are far more likely to be effective if directed at the problem's source.

\section{Which Shareholders Benefit?}

Yet another justification for an expansive role for target management in tender offers admits that shareholders profit from a tender offer, but focuses on the unsavory character of those tendering their

shareholders in cash tender offers. Unless the amounts paid are consumed or invested directly in productive assets by shareholders, the sums must be reinvested in financial assets, either directly or through financial intermediaries. See generally J. VAN HORNe, Financial MARKET RATES AND Flows 1-40 (1978). Thus, Williams's argument cannot be that the funds given to target shareholders are taken out of the financial system by, for example, being stuffed in a mattress. Rather, the argument must be that the new investments do not finance direct investment in real assets. This recharacterization of Williams's position does not alter the response which follows in the text, but merely shifts the inquiry to why the former target shareholders are presented with investment opportunities which favor other than real asset production.

An additional problem with Williams's position is that it views all takeovers as having the same unfavorable results. Even if one ignores eventual reinvestment by target shareholders, recent empirical research indicates that takeovers of smaller high-technology firms are conducive to new production and employment opportunities because "capital formation by [smaller technology-based firms] is enhanced by the possibility that stockholders will eventually be able to sell their stock at a tender offer premium." R. MASULIS, ACQUisition OF Technology-Based Firms by Tender OfFer: An Economic and Financlal ANAlysis 25 (SEC Capital Market Working Paper No. 1, 1980). Also, it has been argued that research and development by smaller firms followed by takeover by larger companies when new products reach the production and marketing stage is an efficient way to organize the innovation process. O. Williamson, MARKeT aND HiERARChIES: ANAlySIS AND ANTITRUST IMPLICATIONS 198-207 (1975); see G. BENTSEN, supra note 3, at 19-26.

126. The factors which might cause management to favor acquisitions over internal expansion in the acquirer's own industry, direct investment in the new industry, or an increase in dividends are discussed in G. BENTSEN, supra note 3, at 12-18. Since target management has had virtually complete discretion to reject tender offers during the period referred to by Chairman Williams, it is hard to see what increasing that discretion will accomplish.

127. H. Williams, supra note 115 , at 82,876 . 
shares. The interests of these shareholders-negatively characterized as speculators or arbitrageurs-in a quick profit are unfavorably compared to the other shareholders' interests in the long-term future of the corporation. ${ }^{128}$ The resulting conclusion, that short-run trading profits are worthy of less consideration by target management than, I suppose, long-term trading profits, is then offered to support management efforts preventing these less worthy interests from prevailing. ${ }^{129}$

Recognizing the actual role of arbitrageurs and speculators in the tender offer process, however, belies the distinction between shortterm speculation and long-term investment. The success of an offer depends on a variety of factors. Arbitrageurs offer to purchase the target's stock at a price equal to the tender offer price discounted by the arbitrageur's evaluation of the risk that the offer will be unsuccessful and that the acquired shares will then be sold in the market at a lower price. ${ }^{130}$ Thus, it is not surprising that arbitrageurs favor a tender offer. In effect, they stand as surrogates, albeit less risk-averse, for long-term investors who have already demonstrated, by selling their shares to the arbitrageurs, that they perceived their "long-term" interests were outweighed by the size of the premium. In other words, the "short-term perspective"131 of the arbitrageurs is a red herring; their desire to sell merely reflects, by proxy, the desires of the selling shareholders.

\section{Management Knowes Best}

A more recent addition to the promanagement portfolio of arguments by Martin Lipton makes no claim about the overall efficiency

128. E.g., Lipton, supra note 105, at 104 ("Many of the lawsuits and much of the agitation for changes in the existing rules come from certain arbitrageurs and professional investors whose short-term perspectives are not in accordance with the long-term interests of other shareholders . . . ."); H. Williams, supra note 115 , at 82,878 ("I [do not] want to see the interests of the long-term shareholder, who behaves as a corporate owner-or of shareholders over time-subordinated to the interests of speculators, who see profits in betting against the corporation."). Professor Sharpe has noted that this type of distinction is often used "simply to denote activities of which the speaker disapproves. One's friends are investors, one's enemies speculators." W. SHARPE, supra note 113 , at 6 .

129. "It would not be unfair to pose the policy issue as: Whether the long-lerm interests of the nation's corporate system and economy should be jeopardized in order to benefit speculators interested not in the vitality and continued existence of the business enterprise in which they have bought shares, but only in a quick profit on the sale of those shares.?" Lipton, supra note 105, at 104 (emphasis in the original).

130. $1 \mathrm{M}$. LIPTON \& E. STEINBERGER, supra note 2, at 20. If arbitrageurs believe competitive bidding will cause the ultimate price to increase, they may pay more than the initial offer price. Id. For a thorough discussion of the mechanics of risk arbitrage, see Wyser-Pratte, Risk Arbitrage, N.Y.U. C.J. Devine INST. FIN. Bull., May 1971, at 1.

131. Lipton, supra note 105, at 104. 
of tender offers, but asserts that interests of target shareholders in a higher return on their investment are best served by allowing management discretion to block a tender offer. Lipton examined 36 unsolicited tender offers that were defeated by targets between the end of 1973 and June 1979 and concluded that "the shares of more than $50 \%$ of the targets are either today at a higher market price than the rejected offer price or were acquired after the tender offer was defeated at a price higher than the offer price." 132 On that basis, Lipton argues that shareholders are best served by giving primacy to target management's judgment.

Lipton's analysis is subject to substantial methodological criticism. He takes no account, for example, of general price movements during the relevant period, ${ }^{133}$ nor is there an effort to discount future values to present values to allow more accurate comparison. And the methodologically more careful empirical studies, albeit limited in number, ${ }^{134}$ are flatly inconsistent with Lipton's conclusions. These studies suggest that following an unsuccessful offer, target company shareholders earn no more than a market return, and that a nontrivial portion of the bid premium is lost. ${ }^{135}$ Indeed, Lipton's data refute his own conclusion. On initial examination, share values of 19 of the 36 target companies considered increased in price, and 17 decreased, relative to the defeated offer, measured as of the earlier of

\section{Id. at 106.}

133. To the extent that the performance of the stocks in the Lipton sample reflects movement in the general price levels of stocks, the same gains would have been available to investors if the tender offer had been accepted through investing it in other stocks, but without giving up the premium offered on the tender.

134. As late as 1977 no study had evaluated the market reaction to unsuccessful tender offers in the United States. Dodd \& Ruback, supra note 116, at 352. A 1976 study had considered the issue with respect to Australian companies. Dodd, supra note 116.

135. See Bradley, Interfirm Tender Offers and the Market for Corporate Control, 35 J. Bus. 345 (1980); Dodd, supra note 91; Dodd \& Ruback, supra note 116; Jarrel \& Bradley, supra note 86; Kummer \& Hoffmeister, supra note 116 . These studies present a consistent pattern. The value of target shares increases substantially around the announcement date of a tender offer to reflect the offered premium. Following defeat of the offer, the target shares drop in value but remain above the original pre-offer price. This pattern suggests, as the investigators describe, that the market views the offer as favorable new information bearing on the future value of the company and, therefore, supporting a higher post-rejection price. Other studies, although not focused on unsuccessful transactions, confirm the value of tender offers and mergers to target shareholders. R. MASUlis, supra note 125; A. OsBORNE, RETURNS TO

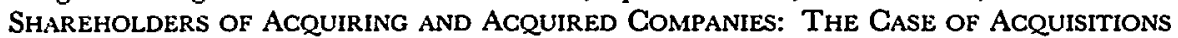
of Technology-BASed FIRMS IN The Over-The-Counter MARKet (SEC Capital Market Working Paper No. 3, 1980); Firth, Takeovers, Shareholder Retums and the Theory of the Firm, 94 Q.J. ECON. 235 (1980). 
August 10,1979, or the date on which the target company was acquired by a different offeror. Of the 19 companies whose share prices exceeded the rejected tender offer, two should be discounted since they appear to have involved transactions in which a white knight made a competitive bid at approximately the same time and in response to the defeated offer. ${ }^{136}$ Further, of the 17 remaining target companies whose shares increased in value beyond the price of the defeated offer, four show increases at a compounded annual rate of less than 3\%, hardly a tribute to management's investment acumen. ${ }^{137}$ Finally, and fully recognizing that my statistical efforts are also misleading, ${ }^{138}$ the subsequent share values of the 36 companies reflect an average compounded annual rate of return to target company shareholders, on the money they would have received if the tender offer had been successful, of $-5.48 \% .^{139}$ In short, the available data, including Lipton's own, support the "popular belief on Wall Street" 140 that shareholders are disadvantaged by defeat of a tender offer.

In an important respect, however, Lipton's data are less important than the argument based upon them. Capital market theory tells us that the market-the shareholders and others acting en masse-is the best unbiased estimate of the value of a corporation's stock. ${ }^{141}$ If target management prevents shareholders from responding to an offer, that valuation process is bypassed. The promanagement argument, however, suggests that management should be allowed to block tender offers, and so "short-circuit" the valuation process, because they are "better" market analysts. But this argument fails for the same reason as the functional equivalence argument: Even if management could "beat the market," there must be a

136. The two targets involved were Latrobe Steel Co. and Unitek Corp. While one might argue that securing a white knight at a higher price justifies management resistance, see notes 173-76 infra and accompanying text, that position is not available to Lipton since he asserts the more extreme position that management should have the discretion to ignore this alternative as well. Lipton, supra note 105, at 109.

137. The four were Vail Associates, Inc., Inspiration Consolidated Copper, BraddockTerry Shoe Corp., and Property Trust of America.

138. Among other problems presented by this shorthand form of data analysis, and which are not presented by the more sophisticated studies referred to in note 135 supra, is the bias toward negative returns resulting from the effect of compounding on more recently rejected offers. Also, I did not weight the various offers by their total value in computing the average, nor have I included dividends paid, if any, in the computation of annual return.

139. This figure excludes the white knight transactions referred to in note 136 supra. If these transactions are included, the figure is $-2.4 \%$.

140. Lipton, supra note 105 , at 106.

141. See note 14 supra and accompanying text. 
mechanism to check management's own interest in the transaction. And if management's superior investment analysis is based on inside information, the only plausible explanation for a claim of unusual ability, eliminating management discretion to block a tender offer does not deprive shareholders of the benefit of this skill. Management may still make public the reasons for its belief that the market undervalues the corporation, ${ }^{142}$ and rational shareholders will not tender at an "inadequate" price unless something in the tender offer process itself prevents realistic shareholder consideration of management's position. It is this point to which the next promanagement argument is directed.

\section{E. The Shareholders Will Make the Wrong Decision}

A different line of argument suggesting that shareholders, left to their own devices, will respond to a tender offer in a manner contrary to their own best interests is based not on the shareholder lack of wisdom, or even on management's superior skill, but on the "special dynamics"143 of the tender offer process. It is argued that, as in the game theorists' "prisoner's dilemma," ${ }^{44}$ it may be in the best interests of each individual shareholder to tender, even if the shareholders as a group ought not to tender. ${ }^{145}$ Unfortunately, the prisoner's dilemma analogy is inapposite.

In game theory terms, the central characteristic of a prisoner's dilemma is an array of benefits and detriments associated with potential courses of action such that, in the absence of cooperation, rational individual behavior yields suboptimal results. ${ }^{146}$ Assume a tender offer is made for $50 \%$ of the shares of a corporation with two $50 \%$ shareholders; that each shareholder must tender all of his shares;

142. Management's possession of nonpublic information which would alter the market's valuation of the target company's stock is not inconsistent with market efficiency in the semistrong form. See, e.g. , J. LORIE \& M. HAMILTON, supra note 14, at 87-96. It must be recognized that management's disclosure of nonpublic information may not always be costless; one can imagine new product and test market information that would have an adverse effect if prematurely disclosed. Real world solutions, however, are not always costless. To condemn improvements by comparison to a hypothetical world where perfection is costless has been aptly called "the 'Nirvana' form of analysis." Jensen \& Meckling, supra note 64, at 328.

143. Lipton, supra note 105 , at 113.

144. See generally A. Rapoport \& A. Chammah, Prisoner's Dilemma (1965). For an easily accessible introduction to game theory see J. Williams, THE COMPLEAT STRATEGY (1966).

145. See Herzel, Schmidt \& Davis, supra note 21, at 154-56; Lipton, supra note 105, at 114; of. Steinbrink, supra note 105, at 896 (individual shareholder decisions create collective decision better made by corporate entity through management).

146. The form of analysis reflected in the following text is drawn from S. BRAMS, PARADOXEs IN POLITICS 79-112 (1976). 
that if both tender, their shares will be taken up pro rata; that the offer is made at a $\$ 5$ premium over market; and that the value of the shares not accepted by the offeror will drop by $\$ 10$. The choices facing the shareholders are expressed in the following payoff matrix.

SHAREHOLDER 2

Don't

Tender

Tender

SHAREHOLDER 1

\begin{tabular}{|cc|cc|}
\hline 0, & 0 & -10, & +5 \\
\hline+5, & -10 & $-21 / 2$, & $-21 / 2$ \\
\hline
\end{tabular}

For the shareholders as a group, the best course of action would be not to tender; any other alternative results in a net loss. If, however, the shareholders must act independently, the optimal result is unlikely to occur. Each shareholder must recognize that if he, seeking the best group outcome, does not tender, and the other shareholder, acting selfishly, does, the selfless shareholder will bear substantial costs. As represented in the northeast and southwest quadrants of the matrix, in that situation the tendering shareholder gains five while the nontenderer loses ten. The rational response, of course, is to tender, thus avoiding all risk of losing ten. Since the decision calculus is the same for both shareholders, both will tender and the offer will be a success even though both shareholders would have been better off had the offer failed. This is the essence of the promanagement argument-that shareholders must tender even though it is not the most desirable result.

The prisoner's dilemma, however, requires that particular conditions be met before pursuing individual self-interest yields less than optimal results. In our example, the crucial characteristic is that the per-share premium (\$5) is less than the amount by which a share either not tendered, or tendered but not accepted, is reduced in value by the success of the offer. ${ }^{147}$ This condition can be stated more generally: A prisoner's dilemma is present only if the gain from the premium offered is less than the anticipated loss on shares retained after the offer's success. ${ }^{148}$

147. This result also depends on the assumption that the shareholders lack an available and enforceable mechanism, for example a trust, which would ensure cooperative action. In light of the transaction costs inherent in shareholder action in a public corporation, the assumption seems a reasonable one.

148. If the sum of the premium on tendered and accepted shares exceeds the sum of the 
This condition should not often be satisfied in a tender offer setting. In typical 2-stage offers, the price paid minority shareholders in the freezeout transaction is no lower than the original offer and occasionally has been higher. ${ }^{149}$ Thus, a shareholder cannot be disadvantaged by following a nontender strategy when failure of the offer is perceived as the optimal collective response, because there is neither incentive for other shareholders to take advantage of his public spirit nor loss to the nontendering shareholder if others' perception of the public good differs from his own. ${ }^{150}$

The potential for a prisoner's dilemma is similarly unlikely in a partial tender where no freezeout transaction is contemplated-the setting presented in the matrix. Consider the offeror's position. The market value of the target's shares declines by $\$ 10$ per share following the offer. If that decline applies to the shares acquired by the offeror as well, then by virtue of the transaction the offeror will have lost $\$ 15$ per share. Alternatively, if the decline applies only to minority shares, then one wonders why only minority shares would suffer so significant a loss. While a possible explanation might be the offeror's opportunity to loot the target, in such extreme settings the fiduciary

decrease in value of the shares remaining outstanding after the offer, then the transaction, taken as a whole, has a positive value for the shareholders and it would be in the best interest of all shareholders, as a group and individually, to tender. As such, the prisoner's dilemma is not present.

149. Dodd \& Ruback, supra note 116 , at 371 , found that minority shareholders in corporations which had been subject to a successful tender offer for control earn significant abnormal returns in the month of the freezeout transaction. A less formal survey found that the freezeout price offered following "any and all" offers averaged approximately $1 \%$ above the original tender offer price. Borden \& Weiner, An Investment Decision Analysis of Cash Tender Offer Disclosure, 23 N.Y.L.S. L. REV. 553, 570 (1978). One would expect the existence of appraisal rights in the freezeout transaction to make unlikely a freezeout price below that at which a majority of the shares had recently traded in an arm's length transaction.

The recent contest between Wheelabrator-Frye Inc. and McDermott Inc. for Pullman Inc. is the only case I know of in which a threat of a freezeout price lower than the tender offer price was used as a strategy to force tenders. At the last stage of the contest, McDermott raised its offer for $54 \%$ of Pullman's outstanding stock from $\$ 34.50$ to $\$ 54.00$ a share, thereby exceeding Wheelabrator's $\$ 52.50$ offer. At the same time, McDermott announced that it would pay only $\$ 39$ per share in the contemplated second-step transaction. In contrast, the second-step transaction contemplated by Wheelebrator carried the same value as the tender offer. The tactic was unsuccessful. Almost immediately following McDermott's announcement, 3,822,000 of the 3,882,000 Pullman shares previously tendered to McDermott were withdrawn. Wall St. J., Sept. 23, 1980, at 4, col. 1; id., Sept. 26, 1980, at 11, col. 1. The result should not have been surprising. The Wheelabrator offer had a combined value of $\$ 594$ million while the combined value of the McDermott offers was only $\$ 525$ million.

150. If the freezeout price is the same as the tender price, shareholders do better to tender because of the time value of money. But the delay between first- and second-step transactions is generally short, and it would take years of delay to turn a typical tender offer premium into an outright loss, and more years until the loss exceeded the premium as the prisoner's dilemma requires. 
duty owed the minority should provide adequate protection. ${ }^{151}$ Existing empirical studies are consistent with this conclusion. The postoffer price of nontendered shares does not fall below their pre-offer price, a result inconsistent with offeror looting. ${ }^{152}$ Thus, the prisoner's dilemma argument simply does not apply to the tender offer setting.

The arguments which suggest that shareholders will choose, or be forced into, conduct which is not optimal even from their own perspective, are thus not convincing. Management discretion to prevent a tender offer simply cannot be justified on paternalistic grounds. If discretion is nonetheless to be accepted, it must be because there are other interests which are benefited by an enlarged role for target management despite the detrimental impact on shareholders.

\section{F. Corporate Social Responsibility}

There is a certain irony in the argument offered by some authorities that responsiveness to nonshareholder constituencies-employees, customers, suppliers, creditors, local communities, and the national economy-justifies management discretion in preventing takeovers. ${ }^{153}$ As Chairman Williams, himself no advocate of shareholder autonomy in tender offers, ${ }^{154}$ states, "[t]he corporate community cannot have it both ways. It cannot argue against added measures-legislative or otherwise-directed to improve corporate accountability by relying on the discipline of the marketplace as a vehicle to depose inadequate management, and then seek to neutralize that discipline by anti-takeover provisions." 155 Nonetheless, since commentators, corporate management, and occasionally courts ${ }^{156}$ as-

151. While there is a good reason to doubt the extent to which fiduciary doctrine provides an effective check against self-dealing in intercompany transactions within an affiliated group, see note 195 infra and accompanying text, the magnitude of the impact on the subsidiaries' operations would not seem large enough to account for a decrease in value of the size specified in the text.

152. Bradley, supra note 135, at 360-65 (on average, target shares' post-successful-offer price exceeds pre-announcement price); Dodd \& Ruback, supra note 116, at 370 (target company post-successful-offer abnormal returns not significantly different from zero); accord, $\mathrm{R}$. MASULIS, supra note 125 , at $18-20$. It should also be noted that in the unlikely event the conditions necessary for a prisoner's dilemma were present, a competing offeror would have an incentive to offer a higher price to the target's holders.

153. E.g., Liman, Has the Tender Offer Movement Gone Too Far?, 23 N.Y.L.S. L. REv. 687 (1978); Lipton, supra note 105, at 105-06, 117; Pearlmutter, supra note 105; Steinbrink, supra note 105 , at $899-900,902$.

154. See notes 125-27 supra and accompanying text.

155. H. Williams, supra note 115 , at 82,881 .

156. Herald Co. v. Seawell, 472 F.2d 1081 (10th Cir. 1972), is the most commonly cited 
sert the argument, it warrants consideration.

A first step is to define "corporate social responsibility." I will adopt David Engel's definition: "the obligations and inclinations . . . of corporations organized for profit, voluntarily to pursue social ends that conflict with the presumptive shareholder desire to maximize profit."157 Note that the definition excludes acts beneficial to nonshareholder constituencies which, although detrimental to profits in the short run, lead to long-run profit maximization. ${ }^{158}$

Second, note that management which engages in acts of corporate social responsibility will rarely, if ever, be held liable for corporate waste. The distinction between corporate altruism and long-run profit maximization is blurred. Whether community aid efforts reflect the corporation's self-interest, however enlightened, or are merely charitable, involves precisely the type of decision review of which the courts appropriately have eschewed by applying the business judgment rule. ${ }^{159}$ So long as management is disingenuous when

case for the proposition that directors have an obligation to consider the interests of nonshareholder constituencies in making corporate decisions, even at the expense of shareholder interests. Herald was a derivative action against management of the Denver Post Co. claiming that a variety of corporate actions were intended to prevent a takeover of the newspaper and to entrench control of the corporation in the founding Bonfils family. Judge Hill presented, albeit in dictum, the most straightforward adoption of the social responsibility position of which I am aware: "We are fully cognizant of the well established corporate rule of law which places corporate officers and directors in the position of fiduciaries for the stockholders. Basic in that rule of law is the profit motive of the corporate entity. In this case we have a corporation engaged chiefly in the publication of a large metropolitan newspaper, whose obligation and duty is something more than the making of corporate profits. Its obligation is threefold: to the stockholders, to the employees, and to the public.

"....

“. . A corporation publishing a newspaper such as the Denver Post . . . has an obligation to the public, that is, the thousands of people who buy the paper, read it, and rely upon its contents. . . Because of these relations with the public, a corporation publishing a great newspaper such as the Denver Post is, in effect, a quasi-public institution." Id. at 1091, 1094-95 (citations omitted).

One is tempted playfully to distinguish the case on first amendment grounds: Only management of "a great newspaper" may resist a takeover despite the uncontroverted benefit to the shareholders. However, other businesses-for example, the proverbial New England town mill-have an equally important impact on the public in their communities, and the intrusion of the first amendment into internal corporate management should be barred by the state action doctrine if nothing else. In any event, it was recently reported that management overcame its belief that "local independent ownership was preferable to chain ownership" and sold the paper to the Los Angeles Times chain. Times Mirror to Buy Denver Post: 895 Million Price Surprises Experts, Wall St. J., Oct. 23, 1980, at 37, col. 4.

157. Engel, supra note 13, at 5-6.

158. Id. at 9. Indeed, recent critics of management attitudes have charged management with an excessively short-term orientation. See, e.g., Rappaport, supra note 66.

159. See notes 8-16 supra and accompanying text. 
necessary, legal standards do not bar management from following a "socially responsible" course. ${ }^{160}$

Thus, to the extent the tender offer process poses a question of corporate social responsibility, the question is not how to define it or whether it is a good thing. Rather, the question raised by asserting that issues of social responsibility justify target management's discretion to block a tender offer is more narrow and ideologically neutral: What checks are there on management's decision to engage in a particular level of nonprofitmaking, altruistic behavior? The issue is whether management-through defensive tactics-may secure immunity from the market consequences of its altruistic decisions comparable to the immunity from legal consequences provided by the business judgment rule.

To be sure, there is something quaint about a general assertion that matters of social responsibility require allowing target management to prevent tender offers; it has the decided flavor of Senator Williams's oft-cited reference, when introducing the Williams Act, to the fate of "proud old companies" at the hands of "white collar pirates." 161 But there is no reason to adopt the assumption that the management of all offerors are less socially responsible than those of all targets. Acts of social responsibility are no more than "a specialized class of suboptimization" 162 by target management which, as with other forms of management discretion which courts cannot effectively regulate, the structure of the corporation relies upon the tender offer process to control. ${ }^{163}$ If shareholders believe management is too responsible for their taste, they will tender their shares at the offered premium, some part of which reflects the potential gain if suboptimization-social responsibility-is reduced. ${ }^{164}$ Thus, to assert social responsibility as a basis for management discretion to block a tender offer is to argue not only that corporate social respon-

160. Engel, supra note 13 , at 63 .

161. 111 CONG. REC. 28,257-58 (1965). It is intriguing that the terms "raider" and "pirate," while often used, are rarely defined. Professor Cary has made one of the rare efforts: "As a Professor, I sometimes define a raider as somebody else's client." Cary, Corporate Devices Used to Insulate Management From Attack, 25 Bus. LAw. 839, 842 (1970).

162. Engel, supra note 13, at 8.

163. See notes 84-98 supra and accompanying text.

164. A decision not to tender need not, however, indicate a shareholder's commitment to corporate social responsibility. Particularly in the case of a "home-town" corporation, the decision of a local shareholder may involve consumption as well as capital gain elements. See generally Grossman \& Stiglitz, On Value Maximization and Altemative Objectives of the Fim, $32 \mathrm{~J}$. FIN. 389 (1977); Hirshleifer \& Riley, The Analytics of Uncertainty and Information-An Expository Survey, 16 J. ECON. LrT. 1375, 1392-93 (1979). 
sibility is a good thing, but that management should have the unrestrained discretion to determine how much corporate capital should be devoted to purposes management deems socially responsible. That position is quite difficult to support, and opposition need not be based on the proposition that corporate altruism results in inefficiency.

The decision as to what activities are socially responsible is a political rather than a corporate or economic one. Target management has no special expertise in such decisions, nor is there any reason to believe that the vision of a just society held by management will be shared by any larger body, whether shareholders or not. ${ }^{165}$ Rather, the issue turns on the appropriate institution to make this type of decision. The tender offer process constrains target management's social as well as business judgments; there is nothing about management's social judgments which renders them more sacrosanct than management's business judgments.

\section{The Appropriate Role for TARget MANAgement}

Examining the common arguments favoring management discretion to block tender offers discloses nothing which justifies interfering with the tender offer's central role in the structure of the corporation. It does not automatically follow, however, that target management has no place in the tender offer process. Indeed, recognizing that the corporate structure assigns to shareholders the decisionmaking role in tender offers helps identify a proper role for management. By focusing on the shareholders' decision, one can identify management functions which aid the shareholder in making the decision and thereby facilitate the proper interaction of the capital market with the corporate structure. These functions derive from the shareholders' need for information and from the inability of shareholders to bargain effectively.

\section{A. Providing Shareholders with Information}

A tender offer requires a shareholder to make one of two types of decisions: (1) in a cash tender offer the shareholder must compare the cash price offered with the present market price of the target security, and perhaps with the potential price of that security at some future point if the offer is unsuccessful; ${ }^{166}$ and (2) in an exchange

165. Engel, supra note 13, at 29-31.

166. Where the offer is for any or all of the outstanding shares, the evidence suggests that a second-step freezeout occurs with sufficient certainty and promptness that consideration of the value of minority shares of target stock following the offeror's taking of control is 
offer the shareholder must compare the expected value of the offeror's security with the present market price of the target security held, and perhaps with the potential of that security at some future point if the offer is unsuccessful. In both settings, shareholders benefit from information which target management may provide most effectively.

Consider first the cash offer. If an offer is made for the target's securities at a premium above the pre-offer price, a rational shareholder will tender in the absence of information concerning the target which indicates that the pre-offer market price was incorrect and that the value exceeds the tender offer price. ${ }^{167}$ The more information available concerning the target company, the more accurate is the market price of target company stock and, therefore, the better the shareholder's decision. Since target management's opposition to the offer, if in good faith, is presumably based on nonpublic information in its possession, such information can be made available at the expense of issuing a press release. ${ }^{168}$ In this setting, target management's presumed interest in defeating the offer will cause them to disclose such information, if it exists. ${ }^{169}$ If the market agrees with management's evaluation of the information, the price of the target's stock will rise above the tender offer price, and the offer will be defeated. Thus, target management's self-interest and target shareholders' interests happily coincide.

Management may also provide information concerning the value of the offeror's securities in the exchange offer setting. Information is not costless; it will be produced only to the point where its benefits

unnecessary. Borden \& Weiner, supra note 149 , at $573-74$. Where the cash tender offer is for less than all of the outstanding shares, it appears that a second-step transaction is less likely and, in any event, less prompt. Id. at 574-75. In that case, the value of the shares in a controlled subsidiary must also be considered.

167. See note 142 supra.

168. But see note 142 supra.

169. It has been demonstrated that, at least in the absence of transaction costs, a competitor will disclose information about the quality of the good being sold without the need for compulsion. Moreover, a seller will have an incentive to take action which demonstrates that its good is better than that being offered by the competitor by taking actions which, in the best of all possible worlds, could not be followed by a lower-quality competitor. Target management is, in effect, selling (convincing its shareholders to retain its stock); it should disclose all favorable information about the target and, in the circumstance of a less than any or all offer in which there is an expectation that there will not be a second-step transaction, all unfavorable information about the offeror. See Beaver, The Nature of Mandated Disclosure, in REPORT ON CORPORATE DisclosuRe, supra note 101, at 637-39; Grossman \& Hart, Disclosure Laws and Takeover Bids, 35 J. FIN. 323 (1980); Ross, Disclosure Regulation in Financial Markels: Implications of Modem Financial Theory and Signalling Theory, in IssuEs IN FINANGIAL REGULATION (F. Edwards ed. 1979). 
equal the cost of production, an equilibrium obviously reached somewhere short of complete information as long as there is a positive production cost. In an exchange offer, target management's advantage lies in its incentive-that of self-interest-to centrally acquire, analyze, and disseminate information concerning the offeror in a more efficient manner than its shareholders and, perhaps, financial analysts. Without this centralized production, two unfavorable results are possible. First, individual shareholders may find the costs associated with evaluating the new securities so great that they do not seriously attempt to do so, even though the information's value to all shareholders exceeds the cost of centrally producing and disseminating it. ${ }^{170}$ Second, even if individual production is worthwhile for larger institutional holders or financial analysts, these parties may not have the incentive to disseminate the information, although the price effects of their acting on it may ease the problem. In any event, central production of the information by a single institution does reduce costs. ${ }^{171}$ Only target management has an incentive, similarly undiluted by free-rider problems, to produce and disseminate such information.

Target management thus has a special role in producing tender offer information, particularly where the information, whether because it favorably reflects the target's future, or unfavorably reflects the value of the offeror securities, suggests that the target's securities have a value higher than that offered. By providing that information, management facilitates shareholder comparison of the value of the target securities with the value of the tender offer. While this can be styled a defensive tactic because it protects target management, it remains desirable because it works through the market for corporate control, rather than by preventing the market from operating by foreclosing shareholder access to an offer. ${ }^{172}$

170. Beaver, supra note 169 , at 635 .

171. It has been argued that the acquisition of information solely for trading purposes may have no social value. If this is correct, there are efficiency gains in having the information produced and disseminated centrally rather than having the same nonproductive information produced independently over and over again. See, e.g., W. BEAVER, Financial REPORTING: AN ACCOUNTING REVOLUTION 46, 194 (1981) and sources referred to therein.

172. It has been argued that any disclosure of information as a defensive tactic is undesirable because it has the effect of reducing the overall incidence of tender offers in the society and, thus, limiting their efficiency-inducing impact. Since information disclosure may also be one form of bargaining, and since the point bears generally on any bargaining role for management, I will consider it in that context. See notes 181-200 infra and accompanying text. 


\section{B. The Bargaining Role-Looking for a White Knight}

It has been widely argued that target management resistance to tender offers, rather than reflecting a self-serving interest in preserving control, is merely the mechanism by which bargaining over price occurs when the formal offer is made to the shareholders rather than to management. ${ }^{173}$ Sellers and buyers enter negotiations with floor and ceiling prices in mind in any exchange; where the actual transaction price reached falls within that range is determined by the parties' strategic behavior. The more specialized form of exchange represented by the tender offer, however, is "complicated because of the fact that a corporation is a common property to its shareholders." ${ }^{174}$ Strategic behavior by multiple sellers-like shareholders in a tender offer-requires incurring coordination costs, which in a public corporation are likely to be prohibitive. ${ }^{175}$ Bargaining by management, in contrast, does not involve shareholder coordination costs and can thus benefit shareholders in situations where the shareholders themselves would not organize. Existing empirical evidence supports this analysis; tender offers initially resisted by management appear to result in higher premiums than offers met by management's approval or neutrality. ${ }^{176}$

Identifying management's appropriate role requires more, however, than merely recognizing the potential value of bargaining to target shareholders. A theme throughout this article has been that management conduct in a tender offer is unavoidably tainted by conflict of interest; recognizing that management opposition to a tender offer may be a bargaining tactic is insufficient, absent a means to distinguish bargaining in good faith from self-serving behavior, where either can result in the offer not being made. ${ }^{177}$ To carve out a

173. E.g., Herzel, Schmidt \& Davis, supra note 21 , at 156-59; Lipton, supra note 105, at 106-08; Steinbrink, supra note 105 , at 893-96.

174. Grossman \& Hart, supra note 169 , at 333.

175. See J. Buchanan \& G. Tullock, supra note 57, at 107-09 ("the costs of securing agreement, within the decisionmaking group, increase as the size of the group increases.") (emphasis in the original). See generally Heymann, supra note 57.

176. P. DAVEY, supra note 2, at 27; Chatlos, The SEC vs. Investors on Tender Offers, HaRv. Bus. REv., Sept.-Oct. 1978, at 6, 7 (reporting an average $75 \%$ premium in friendly offers and $72 \%$ in unfriendly offers, but a $91 \%$ premium where there are competing bids); Kummer \& Hoffmeister, supra note 116, at 511-14; Lipton, supra note 105, at 108 (reporting unpublished study by Goldman, Sachs \& Co. of 85 takeover bids between Jan. 1, 1976 and June 8, 1979 which found that in $95 \%$ of the cases where acquisition followed resistance, the final offer exceeded the original offer).

177. The more balanced proponents of management bargaining recognize the potential for abuse. See, e.g., Herzel, Schmidt \& Davis, supra note 21, at 158. 
bargaining exception from the general prohibition against opposition to tender offers thus requires that the permissible bargaining tactics not have a significant potential for preempting shareholder decisions.

Note that the character of the inquiry has now shifted substantially. We are no longer concerned with whether management should be allowed to defeat an offer-we concluded that the structure of the corporation was inconsistent with allowing management this role-but only with under what circumstances management should be allowed to bargain to improve an initial offer. The issue is now whether the risk of bad faith can be minimized without destroying the potential value of management's bargaining for shareholders.

The professional literature evaluating defensive tactics suggests that if the offeror makes a well-priced cash offer, is patient, and commits no irreparable error, ${ }^{178}$ the offer is likely to get to the shareholders. ${ }^{179}$ If this is correct, the principal bargaining tactic available to management is not the threat of defensive tactics, but obtaining a competitive offer from a white knight. This approach is consistent with shareholder autonomy, the structural principle which should govern the allocation of roles in a tender offer. If the original offer is defeated, the defeat results not from management bargaining, but from shareholder rejection of the initial offer in favor of an alternative offer secured by management. Happily, this tactic also has promise of strategic effectiveness. A higher price merely reduces the potential profit to an offeror without eliminating the incentive to bid. Indeed, information available to management but not to the initial offeror may indicate a higher value for the target, in effect raising an offeror's ceiling price. ${ }^{180}$

In short, if management bargaining tactics are limited to the threat or success of securing a higher offer from another party, then there is little potential for management misusing the bargaining process for self-serving ends, and the possibility for shareholder benefit is still substantial. Put differently, bargaining limited to securing a

178. The most prevalent offeror errors are disclosure problems under the Williams Act, 15 U.S.C. $\$ \S 78 /-78 \mathrm{n}(1976)$. Increasingly, however, courts have allowed the offer to proceed following amendment of the offering material. See generally Wachtell, supra note 2, at 1438. There are, however, situations where the offeror chooses not to amend because it views the disclosure required as imposing excessive substantive costs. See Berman v. Gerber Prods. Co., 454 F. Supp. 1310 (W.D. Mich. 1978) (withdrawal of offer following requirement of disclosure concerning sensitive foreign payments beyond generic disclosure required by the SEC in its voluntary disclosure program).

179. See, e.g., Liman, supra note 153, at 688-89; Reuben \& Elden, supra note 2, at 442.

180. See notes 112-14 supra and accompanying text. 
higher offer is a defensive tactic consistent with shareholder interests because it operates by effectuating rather than interfering with the market for corporate control.

While acknowledging that shareholders of a target company faced with an existing offer will benefit from management bargaining, a number of commentators argue that shareholders of all potential targets as a class, and the economy as a whole, are adversely affected by the potential for such conduct. ${ }^{181}$ The argument is that the threat of a tender offer constrains management's discretion to perform inefficiently or to self-deal. Thus, anything which reduces the incidence of tender offers reduces the power of the threat to constrain management and is detrimental to society.

The problem with competitive bidding in the face of an initial offer, it is argued, is that the initial offeror incurs sunk costs in identifying and evaluating the target company. These investment costs must be covered by expected profit on the takeover. A competing bidder does not incur these sunk information costs, since the target is already identified and target management will assist the competing bidder in evaluating the target's value. As a result, the transaction is profitable for the competing bidder at a higher price than for the initial bidder. This increases the risk associated with investment in takeover investigations and decreases the return associated with those investments. Not only do competitive bids increase the likelihood that a competitor will win, with the result that the sunk costs are entirely lost, but by increasing the price necessary for success, they reduce the potential profit associated with the investment. Therefore, the incentive to make initial offers, and hence the total number of offers, decrease.

I find the argument unpersuasive on a number of levels. First, the sunk cost argument seems to me significantly overstated. In any tender offer of substantial size the information costs associated with identifying and evaluating the target are a small proportion of the entire purchase price, ${ }^{182}$ and the white knight must also incur costs in verifying and assessing the significance of information provided by target management. One cannot help but suspect that success in

181. Easterbrook \& Fischel, The Proper Role of a Target's Management in Responding to a Tender Offer, 94 HARV. L. REv. 1161, 1175-80 (1981); Grossman \& Hart, supra note 86, at 58 n.25; Jarrell \& Bradley, supra note 86 , at $382-87$.

182. For example, the acquiring company's investment banker, which often undertakes the burden of identifying potential targets, appears to earn fees of something less than $1 \%$ of the acquisition price representing, on a $\$ 50$ per share transaction, less than 50 cents per share. Outside Professionals Play an Increasing Role in Corporate Takeovers, supra note 86, at 1, col. 6. 
most major transactions does not turn on differences of this magnitude. $^{183}$

More importantly, I suspect that the sunk costs are investments with a positive expected return even if the offeror is ultimately outbid. Increasingly, a potential bidder takes a substantial block position in the stock of a target before announcing its intentions. ${ }^{184}$ If the initial offeror is outbid, it will simply tender its target shares to its competitor, or sell them in the market, at a per-share profit approximately equal to the premium it initially offered plus the amount by which its offer was exceeded. McDermott, Inc.'s gross profit of approximately $\$ 15.5$ million on shares purchased during its losing contest with Wheelabrator-Frye, Inc. for Pullman, Inc. is illustrative of the phenomenon. ${ }^{185}$

This phenomenon reflects, of course, no more than that the risk of competitive bidding, like most financial risks, can be hedged. The sunk information costs are an investment in a risky asset whose return derives from successfully completing the acquisition and whose risk is that the bidder will lose the acquisition to a higher bidder. Purchase of target shares in the market prior to making the offer hedges that risk because the return on that asset varies inversely with the return on the investment in information. Indeed, if the initial offeror treats the returns associated with a successful acquisition as certain, the effect of the hedge is to allow the initial offeror to guarantee a risk-free return on its investment in information. ${ }^{186}$ Thus, it is

183. The more substantial advantage possessed by the white knight may be its access to more and better information than that possessed by the initial offeror, see notes 112-14 supra and accompanying text, not the ability to free-ride.

184. See note 25 supra.

185. McDermott held 513,000 Pullman shares acquired at an average price of $\$ 22$, for which Wheelabrator-Frye bid \$52. It also held another 60,000 shares acquired at higher prices but below the Wheelabrator offer. Wall St. J., Sept. 26, 1980, at 7, col. 5. Thus, McDermott's gross profit on the transaction was in excess of $\$ 15.5$ million. The total outside expenses incurred by all three parties to the transaction, including investment banker fees, were estimated at only $\$ 17$ million, at least $\$ 6$ million of which was paid by Pullman to its investment banker. See note 86 supra. Even more recently, Seagrams Co. earned $\$ 10,659,750$ on an approximately one month investment of $\$ 13,980,000$ as a result of its loss of St. Joseph Minerals Corp. to Fluor Corp. Seagrams Ends 82.13 Billion Bid for St. Joe, supra note 112.

186. This assumes that there is no risk that the acquisition will fail for other reasons. To be sure, the greater the likelihood that the initial bidder will lose the acquisition to a competitive bidder, the greater the likelihood it will earn the presumably lower risk-free rate. Whether this reduction in return will result in a reduction in the number of initial offers is a function of the potential initial offeror's alternative investments. And even if a reduction in the frequency of initial offers does result, this cost must still be compared to the benefits of competitive bidding. This balance is considered next in the text. 
not at all clear that the potential for competition should reduce the frequency of initial bids. ${ }^{187}$

A second problem with the argument asserting the evils of soliciting competitive bids is that it ignores the efficiency-inducing effect of price competition. As a general principle, allocating resources among competing claimants by price is desirable because it places resources with the most efficient users. To assert that one should maximize the total number of tender offers without regard to the allocative benefits of price competition, one must assume that all offerors can make equally efficient use of target resources. This is unlikely. Indeed, one major explanation for the efficiency of mergerssynergy ${ }^{188}$ - assumes differing abilities to make use of the target's assets. The theory ultimately turns upon the fit of the particular offeror, or the skills of the particular offeror's management, with the target company, and I see no basis for assuming these attributes are identical among competing bidders. Thus, even if competitive bidding reduces the overall number of offerors, the increase in efficiency from allocating target assets to their most efficient user must be balanced against the reduction in efficiency from fewer offers. While this balance cannot be easily identified, the greater the importance of synergy as an explanation for the acquiring company's gains, the more important the efficiency gain through price competition relative to the efficiency loss due to a lower frequency of tender offers. And at least a preliminary sense of the direction of the balance can be gained by examining some of the empirical evidence which has been offered concerning shareholder returns from acquisitions.

187. Indeed, one cannot escape the suspicion that this phenomenon may actually encourage initial offers. If the initial offer is viewed as so distasteful that, at the hint of a takeover threat, the target management will seek a white knight-as seems to be the case with offers made by companies controlled, for example, by Victor Posner-the announcement of an initial block position may make a higher competing bid virtually certain even if the "raider" had no intention of a takeover, but acquired the block hoping to precipitate a competing takeover by someone else. Hirshleifer \& Riley, supra note 164, at 1404-06, identify the potential for realizing through such speculation the value of information produced, and note that the incentive is then to disseminate rather than protect the confidentiality of the information. They also note that the ability to speculate may even lead to "excessive devotion of resources" to the production of new information-in our setting to monitoring potential target companies. Id. at 1405. This would suggest that specialists in monitoring-a new form of information intermediary - would develop, whose interest would be in disclosing the information discovered after taking a speculative position in the potential target's stock, thereby eliminating the sunk cost problem assertedly facing initial bidders. Casual evidence of the extent to which market professionals now play the "takeover game" is consistent with this prediction.

188. See note 119 supra. 
It is helpful to imagine what kind of opportunity might be presented by a target which would be exploitable with equal efficiency by potential acquirers. The example which comes to mind is a target whose management is inefficient in the sense that its managers lack the necessary skills or intelligence-if more talented managers were available, the target company would be more valuable. Assuming that talented management is a commodity generally available to acquiring corporations, an assumption consistent with the evidence that acquiring companies have generally outperformed the market, ${ }^{189}$ the conditions necessary for competitive bidding to result in inefficiency are satisfied. Insight into whether this form of opportunity is the motivation for tender offers can be drawn from available data. If the motivation of a successful tender offer is to increase the efficiency of the target firm, the value of the target firm should increase substantially following the acquisition, and this subsequent increase in target firm value should be the source of the acquirer's gain from the transaction.

The data do not appear consistent with this conclusion. While the price of target company stock increases following completion of the transaction relative to its pre-offer value, perhaps reflecting some gain from the displacement of inefficient management, ${ }^{190}$ "this reevaluation is significantly less than the premium paid target shareholders ... . [A]cquiring firms did not profit from the purchase and subsequent appreciation in the target shares; they suffered an average capital loss of $13 \%$ on each target share they bought."191 The source of gains to the acquirer seems inconsistent with the inefficiency assumption underlying the conclusion that competitive bidding is undesirable. ${ }^{192}$

In what manner, then, do acquiring companies gain from the transaction? The data indicate that gains accrue from increases in the postoffer price of the acquirer's stock. ${ }^{193}$ This is most consistently explained by synergistically motivated acquisitions-_corporate acquirers value target shares primarily for the attached rights to control of the target's resources." 194 If the acquirer can more than proportionately appropriate the synergistic benefit, the postoffer increase in the value of the acquirer's shares will not be matched in magnitude by the postoffer increase in the shares of the target-precisely the

189. See note 116 supra and accompanying text.

190. Bradley, supra note 135, at 364; Jarrell \& Bradley, supra note 86, at 392-93.

191. Bradley, supra note 135 , at 364 .

192. Id. at 350-51.

193. Id. at 365-67; Jarrell \& Bradley, supra note 86, at 381-82.

194. Jarrell \& Bradley, supra note 86, at 381-82. 
result described in the data, and one consistent with the numerous opportunities for the parent company to favor itself at the expense of the subsidiary in an affiliated group setting. ${ }^{195}$

The point may be clarified by referring to a familiar, albeit extreme, example. In Perlman v. Feldmann, ${ }^{196}$ Korean War price controls prevented Newport Steel Company from exploiting the wartime steel shortage by charging a market-clearing price. If a steel consumer gained control of Newport Steel, it would gain the benefit of an assured source of supply in a short market, and so long as it paid Newport only the legally set price, it would appropriate all the synergistic gains from the transaction. The acquirer's gain would then come from the increase in the price of its stock resulting from the value of the "rights to control of the target's resources,"197 precisely the result described by the data. ${ }^{198}$

The data on postoffer prices thus seem more consistent with synergistic motives for acquisitions. And the more synergy explains the gains from the acquisition, the greater the efficiency gains resulting from competitive bidding relative to the efficiency losses from the potential decrease in the number of tender offers.

A final objection to a standard prohibiting a target from seeking competitive bids focuses on a more practical but, I think, equally important level: The role assigned target management by such a standard is unrealistic in tender offer settings. A common opening of the tender offer process is the receipt by the target of a letter asking to negotiate a friendly acquisition, but with the threat, implicit or

195. "The checks on unfair dealing by the parent are few. In theory, of course, the fairness of the parent's behavior is subject to the check of judicial review; but in practice such review is difficult even where the courts have the will to engage in it, and they often lack the will." M. EISENBERG, supra note 28, at 309 (citations omitted); see Cary, supra note 11, at 679-83.

196. 219 F.2d 173 (2d Cir. 1955).

197. Jarrell \& Bradley, supra note 86 , at 382 .

198. The data do not, however, rule out the possibility that the acquirer secures its return by displacing inefficient management but then disproportionately appropriates the gains from increased efficiency. While this result is possible, it seems to me less likely than the synergistic explanation. Appropriation of benefits in a parent-subsidiary relationship takes place through intercompany dealings, like transfer pricing in a vertically integrated affiliated group. The opportunities for such dealings increase with greater operational or financial relations between the parent and the subsidiary. The greater these relations, however, the more likely that there was a synergistic motivation for the transaction in the first place. Of course, even a completely diversified conglomerate can overcharge subsidiaries for central services, like accounting, employee benefit plans and the like, which do not require a special relationship between the characters of the companies, but at the same time the opportunity for misappropriation is of a significantly lower magnitude. 
explicit, of a hostile tender offer if negotiations are refused or fail. ${ }^{199}$ May target management seek alternative offers at this point, or must competitive bidding, if it is to take place at all, only come when the very first contact is initiated by the target? If the latter standard is required, the offeror community should strategically respond by making tender offers as early as possible in order to neutralize target management. But this turns the original justification for the tender offers on its head. Negotiated transactions are preferable because management is more knowledgeable and skillful than the shareholders, and because shareholder action incurs substantial coordination costs. $^{200}$ The tender offer is a monitoring mechanism. If management cannot bargain on the shareholders' behalf, offerors will bypass management entirely. The result is that the monitoring mechanism displaces the activity it was supposed to monitor.

\section{Reducing the Structural Principle to a Rule}

In an important sense, my argument has come full circle. There has never been significant judicial debate over the principle that selfperpetuating action by target management is invalid. The difficulty, I have argued, has been the courts' inability to distinguish defensive tactics from neutral corporate action, particularly where dual effects are present. ${ }^{201}$ The traditional solution-an inquiry into motivefails not in principle, but in implementation, in reducing the principle to a form which meaningfully separates management conduct into valid and invalid categories. This task still remains.

The effort, however, can now begin from a substantially different position. Unlike courts confronting the matter originally, we now understand the tender offer's role in the corporate structure and the relationship between management and shareholders dictated by that role. We have seen that the tender offer is centrally important to the structure of the corporation because it is the key displacement mechanism through which the market for corporate control constrains management behavior and because it is a critical safety valve against management's misuse of its controlling role in all other displacement mechanisms. ${ }^{202}$ Its success depends on independent shareholder action; shareholders tendering their shares transfer control to better

199. See A. FLEISCHER, supra note 2, at 57-59; 1 M. LIPTON \& E. STEINBERGER, supra note 2 , at $40-49$.

200. See notes 101, 175-76 supra.

201. See notes 25-44 supra and accompanying text.

202. See notes 84-98 supra and accompanying text. 
management, and it is the potential for such shareholder action which constrains self-interested behavior by management in connection with mergers and asset sales. A structural approach to allocating responsibility between management and shareholders with respect to tender offers thus yields a straightforward principle: Shareholders must make tender offer decisions.

Before formulating a rule implementing that principle, it is worth pausing to identify the benefits which derive from a structural approach. The major pitfalls facing courts in reviewing management action under traditional standards are no longer present. It is simply no longer relevant to inquire whether management action was in the best interests of the shareholders, a question which, if confronted rather than avoided through the subterfuge of motive, requires judicial review of the alternative futures presented by the contestants for control. The structural principle focuses on how management action affects the role assigned to shareholders, a factual inquiry which ought not to pose special difficulties to courts. This question is one which the court is institutionally competent to answer.

We can now formulate a rule which reflects the allocation of responsibility between management and shareholders dictated by the structurally derived principle. While no model for such a rule exists in this country, extending our vision to the United Kingdom uncovers an approach which, at least in broad outline, seems worthy of emulation.

\section{A. The City Code and a Structural Formulation}

Tender offer regulation in the United Kingdom is bifurcated between governmental regulation and industry self-regulation. The Prevention of Fraud (Investments) Act of $1958^{203}$ and the Licensed Dealers (Conduct of Business) Rules, ${ }^{204}$ together with the Memorandum of Guidance of the Federation of Stock Exchanges, ${ }^{205}$ regulate the formal mechanism by which an offer may be made. However, neither these provisions nor the Companies Act of $1948^{206}$ regulates

203. 6 \& 7 Eliz. 2, c. 45.

204. STAT. INST. 1960 , no. 1216 , reprinted in M. WeINBERG, TAKE-OVERS AND MERGERS 414 app. (3d ed. 1971). These rules are promulgated by the Department of Trade pursuant to $\S 7$ of the Prevention of Fraud (Investments) Act, and are commonly referred to as the Board of Trade Rules. M. WEINBERG, supra, at 111-12.

205. Federation of StOck Exchanges in Great Britain \& Ireland, Admission of Securities to QuOtation: MEMORANDA OF Guidance (1964), reprinted in M. WeINBERG, supra note 204 , at 424 app.

206. $11 \& 12$ Geo. 6 , c. 38 . 
target companies' conduct in response to a bid. ${ }^{207}$ This conduct falls within the City Code on Takeovers and Mergers ${ }^{208}$ which was written and is administered by an industry group, the Panel on Takeovers and Mergers. ${ }^{209}$

The City Code ${ }^{210}$ allocates roles between management and shareholders in a manner similar to that which I have argued derives from the corporate structure. Professor Weinberg, a principal commentator on the Code, has described as one of the "[ $t]$ wo main, though interrelated, threads [which] run through the provisions of the Code . . . that it is for the offeree shareholders to decide whether or not an offer shall succeed."211 The language of General Principle 4 most clearly reflects this theme:

At no time after a bona fide offer has been communicated to the Board of an offeree company or after the Board of an offeree company has reason to believe that a bona fide offer might be imminent shall any action be taken ... which could effectively result in . . .

207. I Palmer's Company Law 858 (22d ed. 1976); Pennington, Takeover Bids in the United Kingdom, 17 AM. J. ComP. L. 159, 169 (1969). Sections 191, 192 and 193 of the Companies Act, however, do constrain the receipt by target management of compensation for resignation of their offices, or for aid in the transfer of control, without approval by the shareholders following disclosure. A. CONARD, supra note 49, at 209-10.

208. Panel on Take-overs and Mergers, The City Code on Take-overs and MERGers (rev. ed. 1976), reprinted in 3 PALMER's COMPANy LAw, supra note 207, at 4505 [hereinafter cited as THE CITY CODE].

209. The Code was originally published in March, 1968, and was the product of a committee organized by the Bank of England. The Committee included representatives of the Accepting Houses Committee (merchant banks), the Association of Investment Trusts, the British Insurance Association, The London Clearing Bankers' Committee (joint stock banks), the Confederation of British Industry, the Federation of Stock Exchanges, and the National Association of Pension Funds. Pennington, supra note 207, at 172. That the self-regulation reflected in the City Code was an effort to head off governmental regulation was openly acknowledged in the Introduction to the April, 1969 edition, reprinted in M. WeINBERG, supra note 204, at 437 app.: "It is generally accepted that the choice before the City in the conduct of Take-overs and Mergers is either a system of voluntary self-discipline based on the Code and administered by the City's own representatives or regulation by law enforced by officials appointed by Government."

While the Code provides a mechanism by which complaints may be made and commented upon, with the decision subject to an appeals process, the Panel has no independent authority to impose sanctions beyond public criticism, although the Stock Exchange Council and other organizations may themselves impose sanctions on members for violation of the Code. M. WEINBERG, supra note 204, at 122, 126-29; Pennington, supra note 207, at 177.

210. The Code consists of 12 General Principles and 39 Rules. In addition, the Panel from time to time issues Practice Notes which clarify the Panel's understanding of one or more of the Principles or Rules. See generally The CITY CODE, supra note 208.

211. M. WEINBERG, supra note 204 , at 123 . The second main thread is "that there must be equitable treatment as between the various shareholders of the offeree company . . .." Id. 
the shareholders of the offeree company being denied an opportunity to decide on its merits. ${ }^{212}$

It is reassuring that a major commercial jurisdiction operates with a rule which allocates tender offer roles in a manner consistent with those which I have argued derive from the structure of the corporation. Beyond reassurance, however, the generality of the approach reflected in General Principle 4 is instructive. It describes the effect to be avoided-interfering with shareholder decision-rather than specifying the particular techniques likely to have that effect. And in contrast to a more detailed code of prohibited conduct, such a general approach is particularly suited to judicial adoption.

These last points raise the questions of the appropriate institution to adopt a structural approach to target company defensive tactics and the form of rule I would propose. I believe it wholly appropriate that courts should undertake the recommended doctrinal shift rather than await the imprimatur of legislative action. In important respects, the operative principle governing the allocation of responsibility for tender offers between management and shareholders is a direct outgrowth of traditional fiduciary doctrine whose development was unabashedly based on the relationships established but not defined by the corporation statute. The principle I have identified does no more than extend that form of analysis-inherently structural in character - to a fiduciary problem-management self-interest with respect to potential changes in control-not adequately treated by present doctrine. This is certainly an important change, but the change reflects an approach pioneered by and entirely suitable for continued development by the courts.

We can now formulate a rule which reflects both the structurally defined roles for management and shareholders and the City Code's attractive general approach. Recognizing that the desired generality lessens the demand upon the drafter, the following is a workable solution:

During the period commencing with the date on which target management has reason to believe that a tender offer may be made for part or all of a target company's equity securities, and ending at

212. The GrTy CODE, supra note 208, Gen. Prin. 4. The terms of General Principle 4 are expanded upon in Rule 38, which provides: "During the course of an offer, or even before the date of the offer if the board of the offeree company has reason to believe that a bona fide offer might be imminent, the board must not, . . . issue any authorized but unissued shares, or issue or grant options in respect of any unissued shares, create or issue or permit the creation or issue of any securities carrying rights of conversion into or subscription for shares of the company, or sell, dispose of or acquire or agree to sell, dispose of or acquire assets of material amount or enter into contracts otherwise than in the ordinary course of business." Id. , Rule 38. 
such time thereafter that the offeror shall have had a reasonable period in which to present the offer to target shareholders, no action shall be taken by the target company which could interfere with the success of the offer or result in the shareholders of the target company being denied the opportunity to tender their shares, except that the target company (1) may disclose to the public or its shareholders information bearing on the value or the attractiveness of the offer, ${ }^{213}$ and (2) may seek out alternative transactions which it believes may be more favorable to target shareholders. ${ }^{214}$

Limiting target management conduct by focusing on its effect on shareholder decision highlights the most important manner in which the rule differs from the traditional inquiry. The central difficulty with the policy conflict/primary purpose test is that it assigns management an important discretionary role in the tender offer process. So long as management "genuinely" concludes that an offeror's policy differs from its own, or otherwise determines that an offer is "not in the best interest of the corporation or its shareholders," traditional doctrine validates defensive action. Subject only to the effectiveness of the defensive tactic selected, target management is, in effect, authorized to act instead of the shareholders. So understood, the common criticism of traditional doctrine-that the tests are indeterminate because it is impossible to differentiate situations where there really are policy differences, or where management really believes it is acting in the best interests of the corporation or shareholders, from situations where such assertions are only a ploy-is beside the point. Under a structural approach the issue is not the wisdom or good faith of particular action, but simply whether, and what kind of, action has been taken. In other words, the approach has the flavor of ultra vires - certain actions are simply outside management's authority.

This distinction, between identifying appropriate areas of management activity and identifying whether particular activity was correct or was taken for proper reasons, also distinguishes the proposed rule from other reform efforts. With few exceptions, ${ }^{215}$ proposed re-

213. Management's role in providing shareholders information is discussed in notes 166-172 supre and accompanying text.

214. Management's bargaining role is discussed in notes 173-200 supra and accompanying text. It should be noted that General Principle 4 has an exception, deleted from the quotation in the text at note 212 supra, for action approved by shareholders. In light of management's advantages in the use of the proxy system, see notes 92-95 supra and accompanying text, I see no reason to substitute a formal vote by proxy for direct shareholder action taken by means of their decision whether to tender their shares.

215. See Easterbrook \& Fischel, supra note 181 (requirement of management passivity); Weiss, Tender Offers and Management Responsibility, 23 N.Y.L.S. L. REv. 445, 453 (1978). It is 
forms, although manipulating the measure or burden of proof, have retained traditional fiduciary analysis as a framework. Thus, critics have suggested that the burden of proof be shifted to management and that management be required to show a "compelling business purpose" for the questioned action, ${ }^{216}$ or that the result of the action was "fair," that defeating the offer would result in shareholders receiving "their highest investment return."218 Alternatively, recognizing the difficulty in separating pure from tainted motives, it has been suggested that procedural, rather than substantive, standards be used to validate management action. For example, Chairman Williams has urged that defensive action by target management be permitted if authorized by independent directors after reasonable investigation. ${ }^{219}$

not entirely clear where Lynch \& Steinberg, The Legitimagy of Defensive Tactics in Tender Offers, 64 CORNELL L.Q. 901 (1979), come out. While the authors correctly focus on tactics which "preclude or otherwise materially impede the target's shareholders' consideration of the offer," id. at 927 , they nonetheless would allow management to show "that the primary reason for the action was not to effectively impede shareholder consideration of the offer," id. at 928, thereby resurrecting motive analysis.

216. This standard was adopted in Klaus v. Hi-Shear Corp., 528 F.2d 225 (9th Cir. 1975), in which a number of defensive tactics were invalidated. Applying California law, Judge Choy rejected the policy conflict/primary purpose approach, id. at 233, and, relying on the California Supreme Court's opinion in Jones v. H.F. Ahmanson \& Co., 1 Cal. 3d 93, 460 P.2d 464, 81 Cal. Rptr. 592 (1969), suggested "a balancing of the good to the corporation against the disproportionate advantage to the majority shareholders and incumbent management." 528 F.2d at 234. The court's explicit reliance on Ahmanson-a case dealing with the obligations of a majority shareholder-as the source of its new rule, and the presence of a majority shareholder in Klaus, leaves unclear whether the court would also reject the policy conflict/primary purpose test when there is no majority shareholder and there is only professional management attempting to protect their positions.

217. Where a decision to adopt a defensive tactic has not been made through a procedurally acceptable mechanism, Gelfond \& Sebastian, Reevaluating the Duties of Target Management in a Hostile Tender Offer, 60 B.U. L. REv. 403, 470-72 (1980), recommend a fairness standard be developed by the courts on a case-by-case basis.

218. Note, Corporate Directors' Liability for Resisting a Tender Offer: Rroposed Substantive and Procedural Modifications of Existing State and Fiduciary Standards, 32 VAND. L. REv. 575, 603-04 (1979) (directors must show that "they reasonably believed, as a result of objective investigation, that defeating the tender offer would yield target shareholders their highest investment return'). Easterbrook \& Fischel, supra note 181, at 1203, would allow, as an exception to their requirement that management remain passive, justification of postoffer tactics by proof that the actions were undertaken for the economic benefit of the target. The rule I propose does not offer such an exception; its unlimited character is discussed in text accompanying note 220 infra.

219. H. Williams, supra note 115 , at $82,880-82$ (use of a special committee of independent directors); $j$ f. Gelfond \& Sebastian, supra note 217, at 467-70 (adoption of defensive tactics by independent directors with professional financial assistance allows application of the business judgment rule). 
The problem with all of these approaches is the underlying premise that target management under some circumstances can preempt shareholder decision in a tender offer. And the mistake of ever allowing target management to displace shareholder decision is exacerbated because neither a "higher" standard nor relying on the decisionmakers' independence provides any guidance in determining the bounds of management's preemptive role. The notion of "compelling business purpose" directs courts to undertake balancing, but does not elucidate what factors ought to weigh in the balance and how much weight should be accorded each. Nor is the failure to delineate target management's role remedied by relying on independent directors. Without substantive guidance as to the appropriate scope of their activity and that of the shareholders, independent directors are left free to define their role themselves. Although presumably less tainted by self-interest, a decision by independent directors to defeat an offer for nonpersonal reasons, such as a sense of responsibility to the town in which the company's major facilities are located, provides only a bootstrap justification for the directors having that discretion in the first place. ${ }^{220}$ The rule I propose suffers neither from indeterminacy nor from lack of a normative foundation. Other criticisms are possible, however, and warrant anticipation and response.

\section{B. Criticisms of a Role Allocation Rule}

\section{Generality of language.}

The generality of the proposed rule suggests the criticism that it will be too ambiguous to provide effective guidance for target management or permit consistent application by judges. What does it mean to "interfere with the success of an offer" or to deny target shareholders "the opportunity to tender their shares"? In this sense the criticism is similar to that directed at the traditional policy conflict/primary purpose test: that it is incapable of reasoned application.

220. A part of the problem turns on the difficulty of defining independence. Even if there are no financial ties between the target corporation and the directors, how independent, at least with respect to the issue of adopting defensive tactics, is a director who is also the chief executive officer of a company perceived as a potential target? The problem is exacerbated since so many outside directors in publicly held corporations are executives with other companies. See, e.g. M. MACE, supra note 78, at 86-110. Thus, while the outside directors may be financially independent-independent with respect to the financial terms of their relationship to the target-they may well not be attitudinally independent-independent with respect to the appropriate role of directors and shareholders in decisionmaking concerning tender offers. 
This kind of criticism, however, focuses on the wrong type of ambiguity. The traditional standard and alternate reforms are ambiguous not because of the generality of their language, but because they reflect no clear notion of the appropriate role of management in tender offers. The proposed rule focuses on the primacy of the shareholder decision: Management actions which facilitate that decision-disclosing information or seeking a better offer-are justified; actions interfering with that decision-such as scorched earth campaigns $^{221}$ or efforts to initiate governmental action against the offeror $^{222}$ - are not. The impact of management action on the opportunity for shareholder decision is a relatively narrow factual question. The ambiguity present in competing standards-the absence of any clear basis on which to determine whether management activity is proper-simply does not exist under the proposed rule. ${ }^{223}$

While criticism of the proposed rule based on the ambiguity of its language may be unwarranted, the rule's generality may elicit a more carefully framed attack. In recent years it has been recognized that, assuming a consistent intent with respect to substantive coverage, the manner in which the activity to be regulated is defined can have an important impact on the results of the regulatory effort. ${ }^{224}$ As an initial matter, a prohibitory rule may be drafted to fit any point along a continuum ranging from generality to specificity. For example, a traffic law could prohibit, on the one hand, driving at an

221. A "scorched earth" defense seeks to convince the offeror that the defense will be so vigorous as to destroy the target's value to the offeror. Gurwin, The Scorched Earth Polioy, INSTITUTIONAL INVESTOR, June 1979, at 33-35. An example of this approach was the successful effort of Houghton Mifflin to convince its authors to advise an offeror that they would sever their relationships with the target if the offer was successful. Id. at $\mathbf{4 0 .}$

222. Interposing governmental regulatory machinery may have the effect of dissipating corporate assets if the result is to limit the target's activity; if directed at the offeror, it may simply increase the effective price to the offeror without increasing the price to the target shareholders.

223. A similar distinction was drawn recently by Professor Chirelstein in considering the prospect of legislative answers to other fiduciary problems. See Chirelstein, Legislative Solutions for Fiduciary Problems, in The Role of the Shareholder in the Corporate World: Hearings Before the Subcomm. on Citizens' and Shareholders' Rights and Remedies of the Senate Comm. on the Judiciany, 95th Cong., 1st Sess. 264 (1977). Noting that "the term 'fiduciary duty' means nothing unless we give it context and state precisely what it is that a fiduciary is obligated to do," id. at 264, Professor Chirelstein concluded that "the problems are complex and cannot be resolved simply through an exercise of intuition about what is fair," id. at 268.

224. See, e.g., R. POSNER, supra note 16, at 424; Ehrlich \& Posner, An Economic Analysis of Legal Rulemaking, 3 J. Legal STUD. 257, 268-69 (1974); Wittman, Prior Regulation Versus Post Liability: The Choice Between Input and Output Monitoring, 6 J. LEgal Stud. 193 (1977). See generally Stone, The Place of Enterprise Liability in the Control of Corporate Conduct, 90 YALE L.J. 1 (1980). The discussion which follows owes much to the Ehrlich \& Posner analysis. 
unsafe speed or, on the other, driving in excess of 35 miles per hour. ${ }^{225}$ In the tender offer context, one might implement the structural principle governing the allocation of management and shareholder roles by a fairly general statement, such as the one I propose, or by specific rules identifying precisely those activities in which management may not engage. Understanding and responding to the criticism that the proposed rule is "too general" means considering the effects on regulatory effectiveness of movements along the generality/specificity continuum.

Professors Erhlich and Posner have demonstrated that, other things being equal, the more specific the prohibition, the less likely it is to deter socially desirable behavior not intended to be prohibited. Uncertainty concerning whether particular conduct is prohibited deters that conduct; precision, by reducing the uncertainty, reduces the unintended deterrence. ${ }^{226}$ The move toward specificity, however, is not costless. The more specific the prohibition, the more likely it is that undesirable conduct, which was intended to be prohibited and would have been covered by a more general prohibition, will not be barred. $^{227}$

Thus, a specific rule deters less, and a general rule more, conduct whether desirable or undesirable. Criticism of the generality of the proposed rule then must be based on the claim that there is a marginal benefit from moving toward a more specific rule-that the benefit from reducing unintended deterrence of desirable activity exceeds the cost of increasing the incidence of undesirable activity. Evaluating such criticism requires both a measure of the amount of activity deterred by a more or less specific formulation and a measure of how desirable is the conduct unintentionally deterred and how undesirable is the conduct intended to be forbidden. ${ }^{228}$

How much activity is deterred? First, consider moving toward a more general rule. In a tender offer this means increasing the risk that a desirable activity-one with an operational benefit but which does not impair shareholder access to an offer, such as the expenditure of

225. Ehrlich \& Posner, supra note 224, at 257.

226. Id. at $262,268-69$.

227. Id.

228. For example, a move to a more specific rule will be desirable if $\Delta D \cdot K_{D}>\Delta U \cdot K_{U}$ where:

$\Delta \mathrm{D}=$ increase in desirable activity

$\mathrm{K}_{\mathrm{D}}=$ desirability coefficient

$\Delta \mathrm{U}=$ increase in undesirable activity

$\mathrm{K}_{\mathrm{U}}=$ undesirability coefficient 
cash on a capital investment-is deterred because of increased uncertainty as to whether it is covered by the prohibition. This deterrence results, of course, from the decision calculus of management-a balance of the potential benefit to the corporation against the risk that the activity will cause the directors to violate the rule.

In this situation, there is an asymmetry in the incidence of potential benefits and burdens resulting from the decision. While the benefits from the activity flow, at least in the first instance, to the corporation, the burden of violation falls on management. ${ }^{229}$ The extent to which desirable activity is deterred by moving toward a more general rule depends on both the extent to which management perceives the benefit to the corporation as a personal benefit and the directors' attitude toward risk.

Next, consider moving toward a more specific rule forbidding precisely identified types of activities. The concern is the extent to which this movement permits undesirable activity-in structural terms, actions which interfere with the shareholders' role in tender offers-because of the increased likelihood that a particular activity will fall outside the rule. In this situation, the decision calculus shifts significantly. Because the activity is undesirable based on our general principle, the benefit of acting-blocking the tender offer-accrues to management, and the burden resulting from the activitythe failure of the offer-will fall on the shareholders.

The foregoing analysis suggests that the character of the decisionmaker is quite significant in determining the impact of alternative formulations of a regulatory principle. ${ }^{230}$ Other things being equal, one would expect a move toward a more general rule to have a greater deterrence effect on desirable activity if the board were independent than if the board were controlled by management. Corporate success determines inside management's professional success

229. Although there has not yet been a monetary recovery from a director for authorizing defensive tactics, the prayers for damages in prominent cases have been enormous. For example, Marshall Fields shareholders requested $\$ 236$ million and Gerber shareholders some $\$ 100$ million. In each case the amount sought represented the entire amount of the lost premium. Gelfond \& Sebastian, supra note 217 , at $648 \mathrm{n} .415$. Additionally, the question has been raised as to whether such damages would be excluded from standard directors' and officers' liability insurance policies. Id. In fact, the measure of damages in this setting is difficult. While the shareholders may have "lost" the premium offered, they would have been required to give up their stock to secure it. The result of the director conduct complained of, however, is that they still have their stock which, presumably, would still command some premium from someone on a takeover. Perhaps the directors should be allowed to secure an alternative takeover following determination of liability in order to "mitigate" damages.

230. Ehrlich \& Posner, supra note 224, at 263, 271. 
to a far greater degree than that of outside directors, so that the benefit from activity which benefits the corporation is more personal to the inside director and, thus, more likely to outweigh the risk of personal liability. Also, outside directors are likely to be more riskaverse than operating management. Reputation and professional standing provide an important source of satisfaction-and future directorships-for independent directors, and these attributes are particularly subject to risk of liability. ${ }^{231}$

The impact of a move toward a more specific rule is also influenced by the character of the decisionmaker. The activity in question is detrimental-antitakeover-so that its benefit, protecting incumbency, is likely to matter more to inside management than to independent directors. Therefore, a specific rule will result in more undesirable activity if the board is management controlled.

Independent directors can then be expected to undertake less antitakeover conduct than management directors with both specific and general rules. ${ }^{232}$ But while this makes independent boards desirable, the possibility of an independent board does not, at first cut, justify preferring a specific or general rule. A closer look, however, indicates that a specific rule may limit the beneficial influence of independent directors.

The more specific a rule, the more likely professional counsel will be relied on to interpret it. ${ }^{233}$ The point can be made by contrasting a general standard-like the best interests of the corporation - which has a large intuitive element, with more complicated rules-like Subchapter $C$ of the Internal Revenue Code-which defy nonexpert interpretation. ${ }^{234}$ Consider the impact of outside advice on independent directors. Rather than being able to form an independent judgment concerning an activity's appropriateness, they must rely on an expert-usually a lawyer. But management, rather than

231. See Gurwin, supra note 221, at 35, 44; Useem, The Social Organization of the American Business Elite and Participation of Corporate Directors in the Governance of American Institutions, $44 \mathrm{AM}$. SOC. REV. 553 (1979).

232. This conclusion provides the conceptual underpinning for the type of reform, recommended by Harold Williams and others, which essentially ignores the substance of the allocation of decisionmaking between management and shareholders in favor of reliance on decisions by independent directors. See note 219 supra and accompanying text.

233. Ehrlich \& Posner, supro note 224, at 270-71.

234. Id ; cf. Clark, The Regulation of Financial Holding Companies, 92 Harv. L. REv. 787, 840 (1979) ("[F]lat prohibitions would probably deter many unfair transactions that would otherwise have been carried out by managers able to persuade themselves and their peers, in view of factual complexities and multiple considerations, that the deals were not clearly unfair."). 
the independent directors, selects and compensates counsel, whether in-house or outside, and counsel thus has a substantial incentive to devise defensive tactics which it can advise the independent directors are lawful. ${ }^{235}$ Counsel's incentive to find the "right" answer is accentuated by the heterogeneous character of the activities which must be covered by the specific rules. If the rule describes the form of the prohibited tactic rather than merely its effect-which is presumably what distinguishes a specific from a general rule-it is likely that motivated, inventive counsel will be able to restructure defensive transactions and tactics to fall outside the form prohibited by the rule without changing the substantive result-a problem which has been endemic to all efforts to regulate commercial transactions. ${ }^{236}$ Thus, more specific rules not only encourage undesirable conduct, but because of the likely role of counsel, they also reduce the benefits one would otherwise expect from the presence of outside directors.

The importance of the deterred activity. The above discussion indicates that a general rule is preferable to a specific rule with respect to the relative amounts of desirable and undesirable conduct deterred. But it may still be that the additional deterrence of a more general rule is less important than the loss of benefits from the desirable conduct unintentionally deterred, even recognizing that specific rules provide less than proportional amounts of deterrence. ${ }^{237}$

In fact, it is not clear that very much desirable activity actually will be deterred by a general rule like that proposed. Most importantly, the proposed rule has a temporal limit which serves to control the extent of its unintended deterrence in a fashion not present with the side effects of a more specific rule. For example, assume that the

235. The general problem of the responsiveness of outside counsel to management has been considered principally in the context of the independence of a director who is also the firm's outside counsel. See Staff of Senate Comm. ON Banking, Housing and URban AfFairs, 96Th CONG., 2D SESS., Report ON CORPorate ACCOUNTABIlITY 452-57 (Comm. Print 1980) and sources cited therein; of. McAdams, A Proposal to Amend the Indemnification Section (\$ 5) of the Model Business Corporation Act, 31 Bus. LAw. 2123, 2138-39 (1976) (suggesting restricted role for "independent legal counsel" in authorizing indemnification of corporate employee).

236. Cf. Deutsch, The Mysteries of Corporate Law: A Response to Bnedney and Chirelstein, 88 YALE L.J. 235, 237 (1978) (Correspondence) ("[T] he clearer and more uniform a rule is, the more likely it is to be regarded as a formality that can justifiably be manipulated so long as compliance with its explicit formulation is maintained."). Perhaps the best example is the "form vs. substance" doctrine in tax law, where the courts have tried to cope with the problem presented by practitioners' ability to restructure transactions in accordance with the terms of the Internal Revenue Code and Regulations without altering their economic substance.

237. Ehrlich \& Posner, supra note 224, at 271. 
proposed rule would have prevented Goodrich from purchasing Gulf's joint venture interest, ${ }^{238}$ and further assume that the purchase was desirable regardless of the Northwest tender. Since the proposed rule is limited to a reasonable period following announcement of an offer, it can only delay, not prevent, the transaction. If the shareholders reject the offer, management is free to proceed with the transaction. And if the offer is successful, new management can proceed with the transaction if it still appears desirable. While there may be some transactions where delay will prove lethal, the number is likely to be small given the overall complexity of major corporate transactions. In a number of the decided cases, including Goodrich, involving activity of the sort which would be deterred by the proposed rule, it was precisely the haste with which the transaction occurred which suggested its defensive character. ${ }^{239}$

The importance of the tender offer in the structure of the corporation, together with the reduction in the deterrent effect of independent directors resulting from more specific rules and the comparatively limited impact of a general rule on desirable activity, reinforce my conclusion that the general approach reflected by the proposed rule is preferable. But while the preceding discussion does confront the criticism that the proposed rule is too general, another criticism can also be anticipated-that the proposed rule is too specific.

\section{The pre- vs. postoffer line.}

The proposed rule, which limits target management conduct only after management becomes aware that an offer is forthcoming, can also be criticized as being too specific in its time dimension. The rule does not proscribe-indeed, does not even address-management conduct occurring prior to awareness of the imminence of a particular offer. ${ }^{240}$ Why, one might complain, is the proposed rule so limited? What constraints apply in the pre-offer period?

238. See notes 35-38 supra and accompanying text.

239. It defies belief that the Goodrich-Gulf transaction, having been dormant for four years, would have been prevented by an additional delay during which Goodrich shareholders determined whether to tender their shares to Northwest Industries. Similar timing issues appear to have been a factor in, e.g., Klaus v. Hi-Shear Corp., 528 F.2d 225, 234 (9th Cir. 1975) ("Hi-Shear did not suggest any compelling reason why ESOT had to be established at a time so advantageous to those in control rather than a few months later . . . ."); Applied Digital Data Sys. v. Milgo Elec. Corp., 425 F. Supp. 1145 (S.D.N.Y. 1977); Royal Indus., Inc. v. Monogram Indus., Inc., [1976-1977 Transfer Binder] FED. SEC. L. REP. (CCH) ף 95,863 (C.D. Cal. 1976).

240. A critic could also argue that terms such as "reason to believe" and "interfere with 
I do not, of course, believe that management should be free to build a defensive fortress in the pre-offer period. Defensive tactics, whether pre- or postoffer, are inconsistent with the allocation of roles between shareholders and management dictated by the structure of the corporation. But while the principle involved in pre-offer tactics is the same, and while it might be possible to extend the rulemaking effort to the pre-offer period as well, I think the need is significantly less pressing than in the postoffer period.

Unlike postoffer defensive strategies, which can be carefully formulated to strike only the interloper without significantly affecting operating performance, pre-offer strategies are necessarily more general. Consider, for example, one possible pre-offer defensive tactic: an acquisition designed to make the company a less attractive target. During the pre-offer period, the target company does not know the identity of the potential offeror nor, in light of the continued popularity of diversifying and conglomerate mergers, perhaps even the potential offeror's industry. Thus, the deterrence must be general. The acquisition must deter undesired offers because it makes the target less desirable generally rather than because it presents a carefully tailored antitrust obstacle. ${ }^{241}$ But to the extent this or other tactics make the target company generally less attractive, such decreased attractiveness should be reflected in a lower price for the company's stock. That decrease, in turn, should leave the target company an equally attractive takeover candidate; indeed, it may have the ironic effect of making the target more attractive, especially if the particular defensive operating strategy adopted can be reversed by the offeror and the effects remedied. ${ }^{242}$ In short, pre-offer tactics are simply less likely to be effective.

the success" may be too general. Whether the criticism is characterized one of ambiguity or of deterring too much desirable conduct, the response has been given in text.

241. This point can be clarified by considering the screening role played by outside counsel. Just as counsel for the offeror is capable of making a reasoned judgment concerning the legality of a proposed acquisition under $\S 7$ of the Clayton Act, 15 U.S.C. $§ 18$ (1976), so may counsel for the target advise on the effectiveness of each potential defensive acquisition in light of the identity of the offeror. Where the offeror is still unknown, counsel's advice is limited to general statements concerning what might help if the potential offeror fell within one or another broad category.

A second example of this point is made in Nathan \& Sobel, supra note 29, in connection with an issuer's repurchase of its outstanding shares as a defensive tactic. While the authors conclude that a pre-offer repurchase of its own shares by a potential target may result in having used "the issuer's cash or credit to finance a portion of the [anticipated] acquisition," id. at 1546-47, they also point out that a repurchase directly from the potential offeror, once the offeror has been identified, "may be an effective way for an issuer to reduce the odds that it will become the target of an unsolicited takeover bid," id. at 1551.

242. The experience of the Kennecott Copper Company illustrates this point. As a re- 
Finally, some of the most popular pre-offer tactics can be dealt with by traditional doctrine. Consider inserting a "change in management" clause in a target company loan agreement. ${ }^{243}$ The corporation cannot be served by the action except to the extent that it is appropriate in all settings for management to prevent displacement. ${ }^{244}$ Traditional doctrine would permit this action in the postoffer period-as long as target management demonstrated that it had a policy conflict with the particular offeror, and that the tactic was an appropriate part of an attempt to defeat the offer. In the pre-offer period, however, the identity of the offeror is not known, so the policy conflict rationale cannot be used to justify the action. ${ }^{245}$ Absent a

sult of the sale of Peabody Coal Company pursuant to the order of the Federal Trade Commission, Kennecott found itself with some $\$ 800$ million in cash and $\$ 400$ million in 30 year notes-a hoard which made it an attractive target. The following year, in a move widely viewed as defensive, Kennecott paid $\$ 567$ million in cash to acquire the Carborundum Company. This acquisition was followed by an accumulation of Kennecott stock by CurtissWright, which then waged an unsuccessful proxy fight for control of Kennecott on the platform that Carborundum should be sold and the proceeds used for a substantial distribution to shareholders. Kennecott Copper Corp. v. Curtiss-Wright Corp., 584 F.2d 1195 (2d Cir. 1978) (discussing history); Kennecott, for Years King of Copper Miners, Suffers String of Crises, Wall St. J., Mar. 5, 1981, at 1, col. 1. To forestall a second round of the proxy contest, Kennecott announced a tender offer for the outstanding shares of Curtiss-Wright, and Curtiss-Wright responded with a tender for its own stock. See Kennecott's Battle with Curtiss-Wright Involves Ambitions, Strategies and Money, Wall St. J., Jan. 5, 1980, at 6, col. 3. The complicated settlement eventually reached by the parties is discussed in Kennecott and Curtiss-Wright End Corporate Battle by Agreeing to a 10-Year Truce Involving \$280 Million, Wall St. J., Jan. 29, 1981, at 3, col. 1. The final chapter in the Kennecott saga was the announcement that it was to be acquired by Standard Oil Co. (Ohio), a transaction reportedly motivated by the weakening effects of the long conflict on Kennecott. Kennecolt Holders Approve Takeaver of Firm by Sohio, Wall St. J., May 6, 1981, at 20, col. 4 .

The consequences of some actions taken by target management, however, may be irreparable. See text accompanying note 117 supra.

243. Such a clause allows the lender to require immediate prepayment if management changes. A. FleISCHER, supra note 2, at 36; 1 M. LiPTON \& E. STEINBERGER, supra note 2, at 272.

244. While there are circumstances where a change in control clause is desired by the lender or other party to the supply relationship, the basis is that party's concern that a change in management would affect the corporation's credit-worthiness or ability to perform. If the clause is proposed by the target, there is at least a strong implication that it is not independently attractive to the other party and, therefore, the target will receive nothing in exchange for limiting its future flexibility.

245. Shark repellent amendments-alterations in the company's articles of incorporation or bylaws designed to make the company a less attractive target-present a number of issues different from those posed by other defensive tactics, issues that make more difficult the application of either traditional doctrine or a structural approach. First, the crucial characteristic of shark repellent amendments-supermajority vote requirements-appears to be expressly contemplated by the common statutory authorization of shareholder vote requirements higher than those specified in the statute. E.g., CAL. CORP. CODE $\S$ 204(a)(5) 
promanagement shift in the traditional standard, pre-offer tactics which can have no business purpose should thus be in jeopardy under the traditional measure of management's fiduciary duty. ${ }^{246}$

\section{CONCLUSION}

Almost twenty years ago Bayless Manning announced the death of corporation law "as a field of intellectual effort." ${ }^{247}$ Noting the demise of the nineteenth-century notion that the corporation, like $\mathrm{Pi}$ nocchio, was to be treated like a "real boy," Manning offered the following image:

When American law ceased to take the "corporation" seriously, the entire body of law that had been built upon that intellectual construct slowly perforated and rotted away. We have nothing left but our great empty corporation statutes-towering skyscrapers of

(West Supp. 1981); Del. Code ANN. tit. 8, § 102(b)(4) (1975); ABA-ALI MOdel Bus. CoRP. AcT ANN. 2D $\S 143$ (1971). This barrier is not presented by other defensive tactics. Second, shark repellent amendments are commonly adopted in the pre-offer period, thus falling outside the scope of the proposed rule. Because some forms of amendment have justifications other than their impact on potential offerors, traditional fiduciary doctrine also has little promise of effectively controlling them. Resolution of these problems requires more attention than is possible here and is the subject of my forthcoming article, The Case Against Shark Repellent Amendments.

246. A possible problem with my view that the proposed rule is an outgrowth of existing law, however, is the reference in recent judicial opinions to an affirmative "duty to defend" against undesirable tender offers. Because this doctrine may be seen as explicitly acknowledging a management role which conflicts with the proposed rule, some attention to its origin and content is appropriate. The notion arose initially as unsupported dictum in an opinion justifying defensive tactics in the postoffer period by application of the traditional standard. Northwest Indus., Inc. v. B.F. Goodrich Co., 301 F. Supp. 706, 712-13 (N.D. Ill. 1969) ("[M]anagement has the responsibility to oppose offers which, in its best judgment, are detrimental to the company or its shareholders."). It has since become commonplace. See, e.g., Treadway Cos., Inc. v. Care Corp., [1980 Transfer Binder] FED. SEc. L. REP. (CCH) I 97,603 (2d Cir. 1980); Heit v. Baird, 567 F.2d 1157, 1161 (1st Cir. 1977); Panter v. Marshall Field \& Co., 486 F. Supp. 1168, 1195 (N.D. Ill. 1980), affd, Nos. 80-1375, 80-1389 (7th Cir. Apr. 2, 1981); Berman v. Gerber Prods. Co., 454 F. Supp. 1310, 1323 (W.D. Mich. 1978).

Although neither analysis nor authority for the concept has yet been offered, it has been repeated, albeit apparently in dicta, with sufficient frequency that it may be viewed as a barrier to judicial adoption of the rule I propose. It is thus important to understand that a suitably limited "duty to oppose" is not inconsistent with the proposed rule's limits on activity by target management during a tender offer.

Under the proposed rule management opposition to an offer which takes the form of providing information to shareholders or of securing alternative offers is permissible because such activity facilitates shareholder decision rather than supplanting it. As so limited, a management duty to oppose a proposed tender offer may indeed be in the shareholders' best interests. Under these circumstances, of course, the appropriate measure of management's satisfaction of its "duty" would be the business judgment rule.

247. Manning, The Shareholder's Appraisal Remedy: An Essay for Frank Coker, 72 YALE L.J. 223, 245 n.37 (1962). 
rusted girders, internally welded together and containing nothing but wind. ${ }^{248}$

A structural approach to the corporation, here used to allocate responsibility between management and shareholders in tender offers, is an effort to add substance to the abandoned statutory skeleton described by Manning by integrating the influence of the markets in which the corporation and its participants function. But while that substance derives from developments in modern economic and financial theory, more is required to rehabilitate the intellectual edifice of corporate law than simply recognizing the existence and importance of related disciplines. ${ }^{249}$ We must mesh the insights of those disciplines with legal doctrine if courts and legislatures are to successfully adopt new standards for management and corporate behavior.

The structure which results is a statutory framework buttressed by behavioral engineering. It promises an integrity which nineteenth-century corporate legal fiction never possessed, and an institutional setting which a purely behavioral insight cannot provide. The structure thus recognizes the importance of markets in giving substance to the statutory skeleton, and places them in the regulatory context in which they function.

248. Id.

249. One ought not, however, to underestimate the importance of that recognition. The major books used to teach basic corporations and securities law, e.g., W. GARY \& M. EISENBERG, supra note 104; R. JenNings \& H. MARSh, supra note 101; D. RATNER, SeCURIties Regulation (2d ed. 1980); D. Vagts, Materials on Basic Corporation LaW (2d ed. 1979), are almost entirely silent with respect to the relevance of economic and financial theory. Recent and very helpful exceptions include V. BRUDNEY \& M. CHIRELSTEIN, supra note 71; ECONOMICS OF CORPORATION LAW AND SECURITIES REgULATION, supra note 116; W. Klein, Business Organization and FinanCe (1979). 